\title{
A Review of Earth Observation-Based Analyses for Major River Basins
}

\author{
Soner Uereyen $1, * \mathbb{C}$ and Claudia Kuenzer ${ }^{1,2}$ \\ 1 German Remote Sensing Data Center (DFD), German Aerospace Center (DLR), Muenchener Strasse 20, \\ D-82234 Wessling, Germany; Claudia.Kuenzer@dlr.de \\ 2 Institute for Geography and Geology, University of Wuerzburg, Am Hubland, \\ D-97074 Wuerzburg, Germany \\ * Correspondence: soner.uereyen@dlr.de
}

Received: 7 November 2019; Accepted: 6 December 2019; Published: 9 December 2019

\begin{abstract}
Regardless of political boundaries, river basins are a functional unit of the Earth's land surface and provide an abundance of resources for the environment and humans. They supply livelihoods supported by the typical characteristics of large river basins, such as the provision of freshwater, irrigation water, and transport opportunities. At the same time, they are impacted i.e., by human-induced environmental changes, boundary conflicts, and upstream-downstream inequalities. In the framework of water resource management, monitoring of river basins is therefore of high importance, in particular for researchers, stake-holders and decision-makers. However, land surface and surface water properties of many major river basins remain largely unmonitored at basin scale. Several inventories exist, yet consistent spatial databases describing the status of major river basins at global scale are lacking. Here, Earth observation (EO) is a potential source of spatial information providing large-scale data on the status of land surface properties. This review provides a comprehensive overview of existing research articles analyzing major river basins primarily using EO. Furthermore, this review proposes to exploit EO data together with relevant open global-scale geodata to establish a database and to enable consistent spatial analyses and evaluate past and current states of major river basins.
\end{abstract}

Keywords: major river basins; catchment; watershed; Earth observation; remote sensing; spatial analyses; land surface; surface water

\section{Introduction}

\subsection{Relevance of River Basins}

Since the origin of ancient civilization, human activity primarily evolved in regions where the Earth's surface is shaped by rivers [1]. In terms of freshwater supply and food production, rivers are essential to human societies [2]. At the same time, rivers are systematically exploited for extensive irrigation, transportation, or hydropower generation. Mesopotamia, also referred to as cradle of civilization, is formed by the Tigris and Euphrates river system providing fertile soils as well as direct access to freshwater for livelihoods and agricultural productivity. However, the Tigris-Euphrates river basin has faced extreme drought events over recent decades that have contributed to agricultural failures [3]. In comparison, the Mekong river, considered to be the lifeline of Southeast Asia, has undergone vast human-induced changes. The natural river flow has been thoroughly modified through the construction of dams with a tremendous impact mainly on biodiversity and sediment transportation [4]. A decrease in sediment transportation from the Mekong river to the sea already resulted in large-scale erosion at its delta [5]. 
Growing human societies, increasing demand for freshwater, and global climate change put high pressure on river systems and their entire drainage area [6-8]. As freshwater is not evenly distributed on the globe, many regions must deal with water scarcity [9]. In this regard, Mekonnen and Hoekstra [10] reported that around 4 billion people suffer severe water scarcity over a period of at least 1 month a year. With accelerating climate change, the number of people affected by climatic and hydrological extreme events might increase considerably.

In the light of land and water resource management, monitoring of rivers and their entire drainage area is highly important [11]. With more detail, the drainage area of a river, also called river basin, covers all parts of the land surface that contribute to the river discharge at a certain point. In fact, river basins are a functional unit of the Earth's surface with unique characteristics with respect to their land surface properties, topography, geology, and climate. Here, it is important to note that any changes made in the upstream area might have a considerable impact on downstream regions. Therefore, governance of major river basins, particularly transboundary river basins where collaboration between nations is a prerequisite for avoiding political conflicts [12], is of utmost significance with respect to environmental health and economic development. Figure 1 briefly visualizes selected features and processes of a river basin.

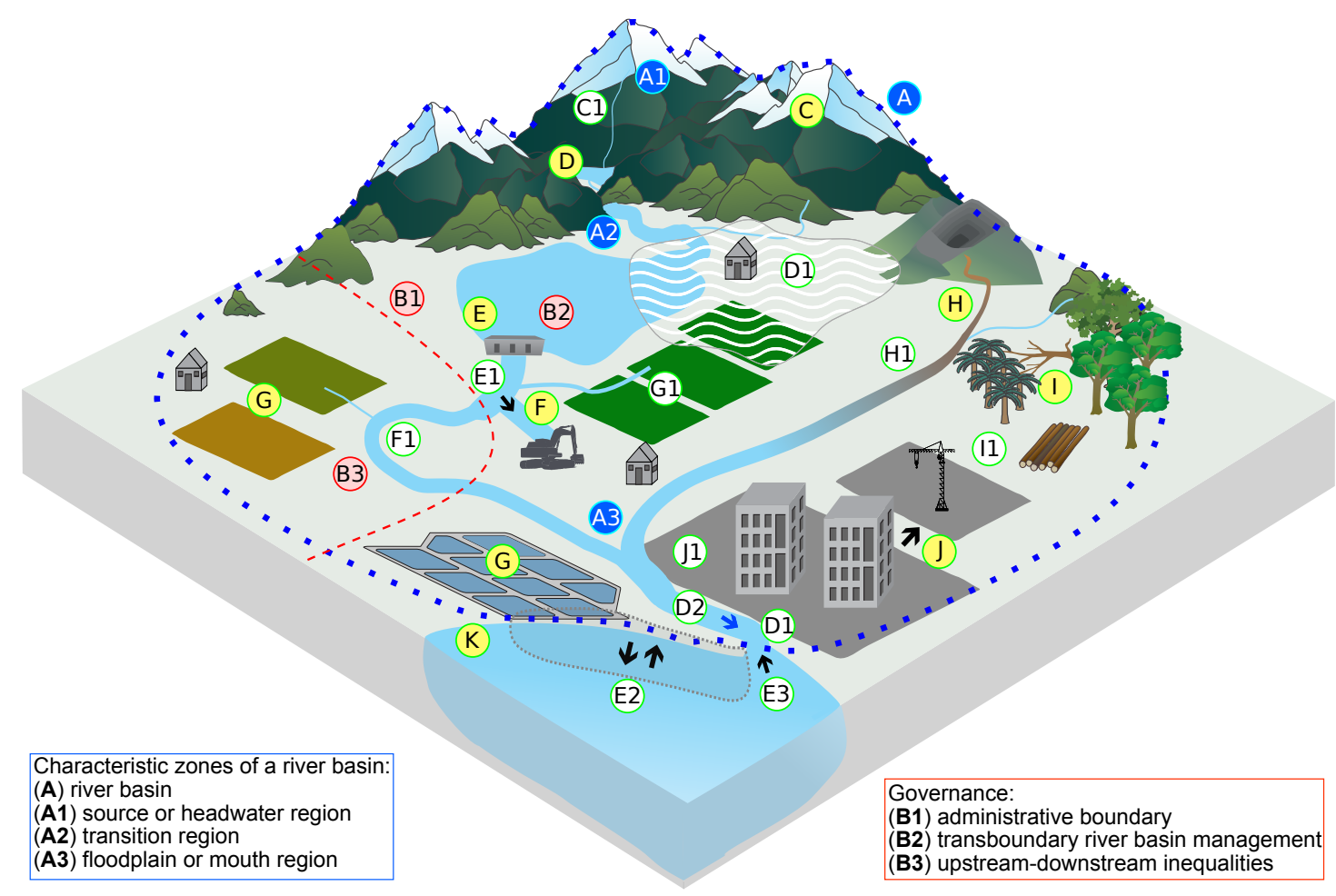

Land surface parameters:

(C) snow cover, glacier, permafrost, (D) water bodies, (E) dams, (F) artificial channels, (G) agriculture and aquaculture,

(H) water quality, (I) forest and vegetation condition, (J) settlement areas, (K) coastline

Land surface and surface water processes:

(C1) surface runoff, (D1) inundation and flooding, (D2) river discharge, (E1) disturbance of natural river flow impacting

biodiversity and sediment transportation, (E2) accretion and erosion depending on sediment transport, (E3) saltwater intrusion,

(F1) river flow modification, (G1) irrigation, (H1) water pollution, (I1) deforestation and monoculture tree plantations,

(J1) land sealing and increased surface runoff

Figure 1. Schematic overview of a river basin showing selected land surface parameters and related processes (several symbols used are adopted or modified according to courtesy of the Integration and Application Network, University of Maryland Center for Environmental Science). 
River basin management requires comprehensive monitoring of its unique characteristics. To date, there are several inventories and interactive data portals providing information on selected major river basins. AQUASTAT, maintained by the Food and Agriculture Organization (FAO), provides tabular inventories on water resources, dams, and irrigation characteristics, but just at the spatial entity of countries. Additionally, a detailed geographical description is available for a selection of transboundary river basins only. Furthermore, HydroSHED provides a suite of geospatial datasets related to hydrographic information on river basins at global scale [13]. The Global Runoff Data Centre (GRDC) offers geospatial datasets on river basin boundaries as well, including tabular inventories on drainage area and mean annual discharge. Additionally, the United Nations Environment Programme (UNEP) coordinates the Transboundary Waters Assessment Programmes (TWAP) river basin component. This platform quantifies baseline information for all transboundary river basins at global scale, including indicators such as water stress, water pollution, governance aspects, and socio-economic variables mainly focusing on risks related to the environment and society. In addition, the World Resources Institute (WRI) provides geospatial information on water related topics, such as water risk on the Aqueduct platform. However, an exploitation of available geospatial thematic data as well as a consistent monitoring of the spatial and temporal distribution of land surface and surface water properties lack for major river basins at global scale [14-16]. In Figure 2 general characteristics of major river basins, such as basin area, measured mean annual discharge, population data, and change of selected land cover information are described. 

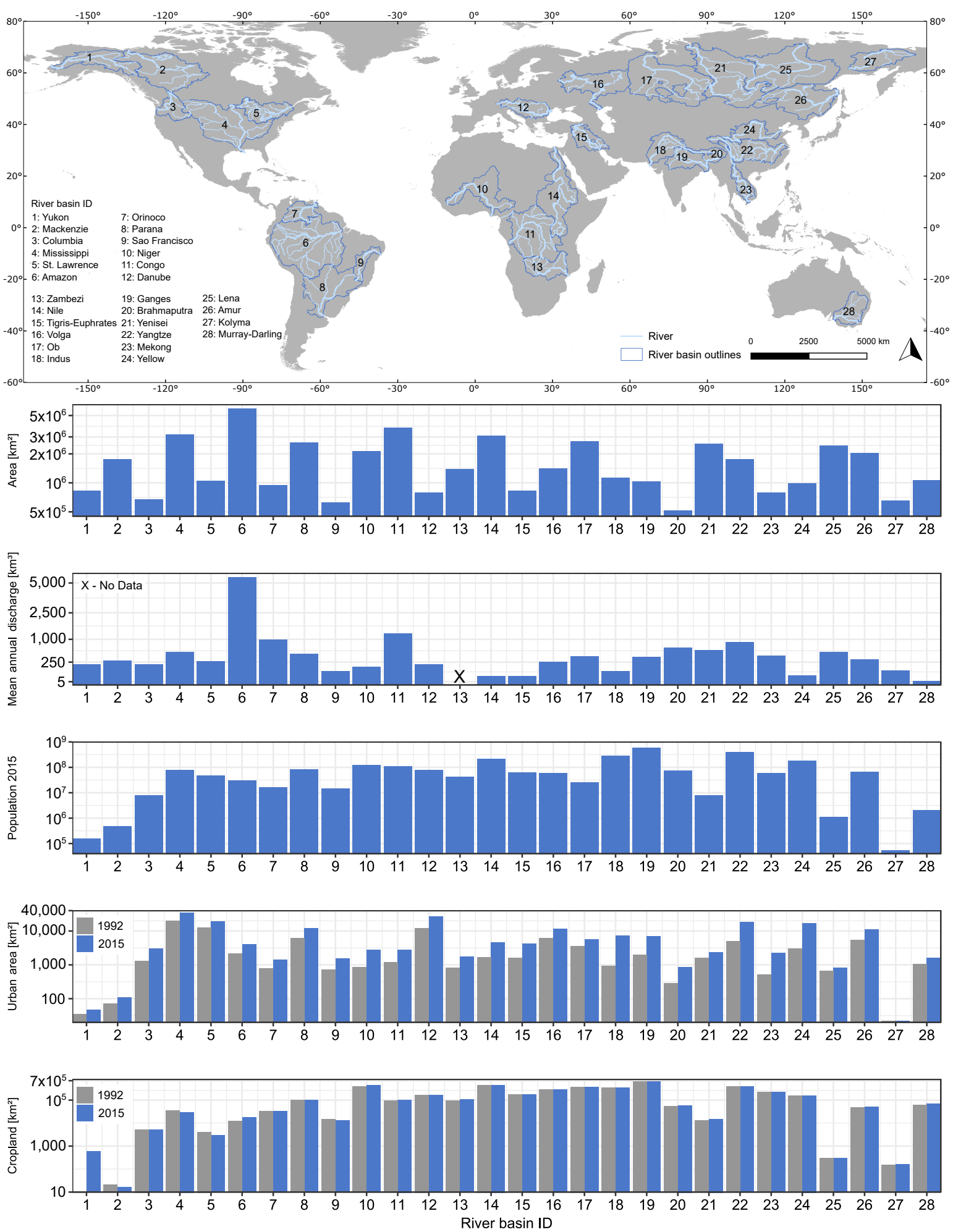

Figure 2. Characteristics of selected major river basins (selection procedure is described in Section 2). River basin outlines and data on river basin area and discharge are obtained from the Global Runoff Data Centre (GRDC) [17]. Population data is extracted from CIESIN population dataset [18] and spatial information on urban areas as well as rainfed and irrigated croplands from European Space Agency's (ESA) Climate Change Initiative (CCI) Land Cover [19]. 


\subsection{Earth Observation in Times of Open Archives}

Considering the large size and spatial as well as temporal variability of major river basins, Earth observation (EO) has the potential to serve as an efficient tool for river basin characterization. This includes direct and indirect measurements e.g., on land cover and land use, surface water, and river or lake water levels.

The open data policies for many satellite programs offer free access to data archives, e.g., from the European Copernicus Sentinel or the USGS Landsat and MODIS missions, including optical, synthetic aperture radar (SAR), or altimetry instruments. Depending on the requirements and research questions, analyses of land surface and surface water dynamics can be performed at high to low spatial resolution (10 to $1000 \mathrm{~m}$ ) covering local to global scale. Here, the temporal resolution of change analyses highly depends on the selected data source. Long-term analyses are possible at medium spatial resolution (30 m) e.g., using optical Landsat data (since 1972). Landsat data have the potential to retrieve information on e.g., land cover and land use, vegetation condition, or water clarity at a revisit time of 16 days $[15,20,21]$. Considering time-series analyses, the low revisit time and data gaps of multispectral Landsat images caused by cloud coverage might drastically reduce the number of valid observations. However, incorporating multi-source Sentinel-2 imagery (since 2015) at 10 to $20 \mathrm{~m}$ spatial resolution and a revisit time of up to 5 days, it is possible to densify time-series of optical imagery at high spatial resolution. On the other hand, MODIS (since 2000) and NOAA-AVHRR (since 1978) provide multispectral imagery at low spatial resolution ( 250 to $1 \mathrm{~km}$ ) with the advantage of very high temporal resolution up to twice a day. These data offer the opportunity to perform time-series analyses at very high temporal resolution, e.g., to monitor crop growth or inundation dynamics [22,23]. In comparison, SAR missions have the capability to observe land surface dynamics independent of illumination and weather conditions. In detail, open SAR data is provided e.g., by the Sentinel-1 mission at a spatial resolution up to $10 \mathrm{~m}$ and a temporal resolution up to 3 days. SAR data have the potential to characterize e.g., inundated areas with or without vegetation cover [24,25].

\subsection{Objectives and Scope of this Review}

In this review, we analyze all available studies focusing on EO-based characterization of river basins and we assess how EO can contribute to quantifying land surface and surface water parameters with respect to major river basins. To our knowledge, there is no review article mainly focusing on EO-based applications in the context of large river basins. However, we identified related reviews e.g., investigating the use of EO in characterizing surface water [14], EO for monitoring river corridors [26], EO for water resources management [11], EO for monitoring flood extent and water level [27], or application of EO in hydrology [28,29]. The overarching objective of this review is to analyze EO-based datasets and their respective spatial and temporal scale. For this purpose, we review all available literature and provide a general overview of what type of information has been made available to date. In this context, the following research questions will be addressed:

- Which land surface and surface water parameters are studied for major river basins?

- Which remote sensing data sources are used in the reviewed articles?

- What is the availability of basin wide studies, also with respect to the analyses of transboundary river basins?

- What are the limitations of major river basin analyses and what are challenges for future studies?

In Section 2, we start with the description of the methodological review approach. In the following, we present the results of the literature review in Section 3. With more detail, we provide a broad overview of the reviewed studies that investigate river basin characteristics using satellite data. Here, we focus on parameters, such as the spatial distribution of the studies, the identified research foci, employed sensor types, temporal resolution, and spatial scale of the reviewed studies. We also elaborate relevant open geospatial datasets describing land surface and surface parameters at global 
scale. Afterwards, a detailed review of the investigated land surface and surface water parameters is given. Next, we discuss the findings of our review in Section 4. In Section 5, the review is summarized focusing on the main findings.

\section{Methodology}

We collocated all available research articles investigating land surface and surface water parameters, specifically those measurable directly at the Earth's surface, using primarily spaceborne remote sensing data. In the literature, a major river basin is categorized e.g., based on its mean annual discharge, total length of the river, or total size of the drainage area. In this review, the selection of major river basins is solely based on their drainage area. To incorporate at least one major river basin per continent, we selected all river basins with a drainage area greater than $500,000 \mathrm{~km}^{2}$. It must be noted that lake drainage areas are not considered for this review. The resulting sample size amounts to the 28 largest river basins, visualized in Figure 2.

Literature search has been conducted based on the bibliographic database of Web of Science and Scopus (last accessed on 09.04.2019) including research articles of the last two decades, specifically published between 2000 and end of the first quarter of 2019. During literature search we used the names of the selected major river basins together with additional keywords including 'river', 'delta', 'basin', 'catchment', 'watershed', or 'floodplain'. This search query resulted in a very large number of research articles. Hence, we reduced the number of journals by pre-selection, since this review focused primarily on EO-based studies of river basins. In particular, this pre-selection limited the literature search to 14 relevant journals and was conducted based on criteria such as compliance of the scope between journal and literature review and relevance of the published research articles. The selected journals as well as the number of identified research articles are listed in Table 1. Accordingly, the research focus of the selected journals is on EO, geoscience, and hydrology. In a final step, we screened all resulting literature based on the following inclusion criteria:

- The literature addressed EO-based land surface and surface water characterization.

- The research article investigated the spatial entity "basin", "subbasin", or "regional". Studies with a small local study area are excluded.

- The research article employed primarily spaceborne EO data.

- The research article did not focus on sea surface water or land-atmosphere interaction applications.

The remaining 287 studies were analyzed to extract relevant information for this review, such as the parameters research focus, employed remote sensing sensor, spatial scale of the study area, and temporal resolution of the study (see Supplement Table S1). Regarding the thematic focus of this review, the research articles were categorized into "biosphere", "hydrosphere", and "cryosphere". Studies analyzing urban areas were assigned to the category "biosphere". Throughout the literature review, research foci were identified and associated with one of the defined spheres. Corresponding research foci are listed in Table 2. 
Table 1. List of included journals and the corresponding count of reviewed articles.

\begin{tabular}{ll}
\hline Journal Title & Number of Articles \\
\hline Remote Sensing of Environment & 75 \\
\hline Remote Sensing & 62 \\
\hline International Journal of Remote Sensing & 59 \\
\hline Applied Geography & 12 \\
\hline $\begin{array}{l}\text { International Journal of Applied Earth Observation } \\
\text { and Geoinformation }\end{array}$ & 11 \\
\hline Hydrological Processes & 11 \\
\hline IEEE Transactions on Geoscience and Remote Sensing & 9 \\
\hline IEEE Journal of Selected Topics in & 8 \\
\hline Applied Earth Observations and Remote Sensing & 7 \\
\hline Science of the Total Environment & 7 \\
\hline Hydrology and Earth System Sciences & 5 \\
\hline Journal of Applied Remote Sensing & 5 \\
\hline Journal of Hydrology & 5 \\
\hline Environmental Earth Sciences & 4 \\
\hline Photogrammetric Engineering and Remote Sensing & 4 \\
\hline ISPRS Journal of Photogrammetry and Remote Sensing & 3 \\
\hline Water Resources Research & 287 \\
\hline$\sum$ & 4 \\
\hline
\end{tabular}

Table 2. Summary of categories and corresponding research foci.

\begin{tabular}{ll}
\hline Category & Research Focus \\
\hline Biosphere & Agriculture, coastline, land cover and land use, urban, vegetation \\
Hydrosphere & River discharge, river water level, surface water, water quality \\
Cryosphere & Permafrost, river and lake ice, snow and ice cover \\
\hline
\end{tabular}

\section{Results: EO Applications for River Basins}

In this section, we first provide a broad overview of the spatial distribution of the reviewed studies and their respective research foci. Afterwards, we evaluate the used sensor types, the temporal resolution as well as the spatial scale of the reviewed research articles. In the following, a more detailed review of the identified research foci is provided presenting key results and findings of the reviewed studies.

\subsection{Spatial Distribution of Reviewed Research Articles}

The results of this review revealed that analyses of land surface and surface water parameters mainly focused on selected major river basins. The frequency of studies with respect to each individual river basin as well as country are compiled in Figure 3. In detail, we found that the number of published studies is highest for the Amazon river basin, specifically, it was investigated by $\sim 21 \%$ of all reviewed studies. Also, we identified a high research interest for river basins in Southeast Asia, specifically the Yangtze, Mekong, and Yellow river basin. In particular, the percentage of research articles analyzing these river basins amounts to $\sim 15 \%, \sim 15 \%$, and $\sim 9 \%$, respectively. Even though the Congo river basin is the second largest in the world, it was investigated in only $\sim 6 \%$ of the reviewed articles. Furthermore, the Mississippi and Mackenzie river basins, located in North America, have 
a share of $\sim 5 \%$ each. With respect to Arctic river basins, Figure 3a demonstrates that the number of reviewed studies is comparably low, i.e., 2 studies for the Kolyma [30,31] and Volga [32,33] river basins, respectively. To our knowledge, no studies have been conducted for the Amur river basin.

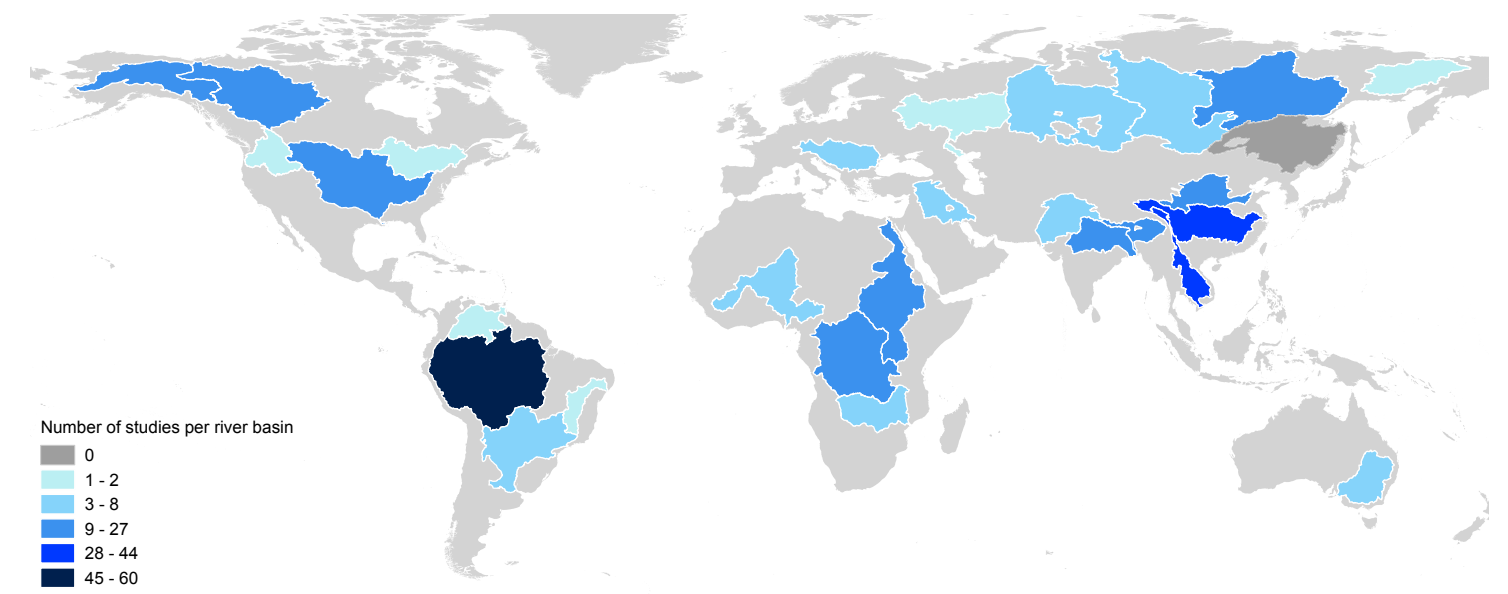

(a)
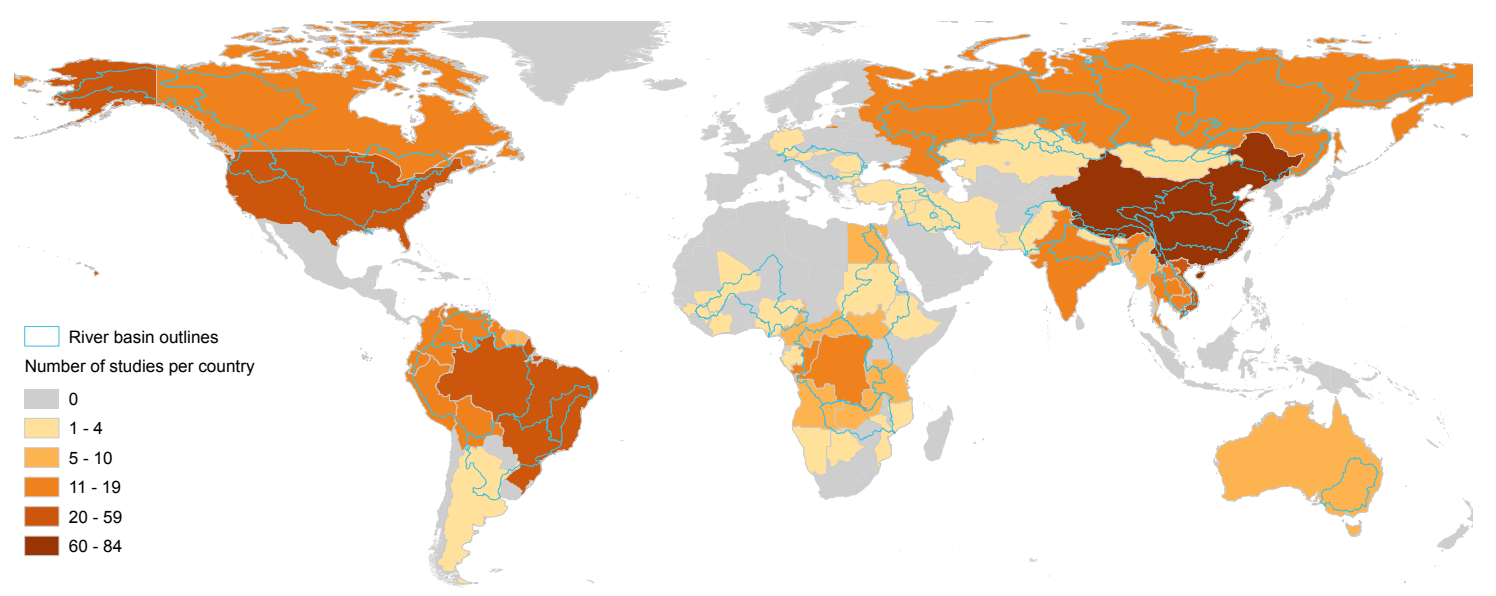

(b)

Figure 3. Overview (a) of the frequency of reviewed research articles per major river basin and (b) the frequency of reviewed research articles per investigated country.

In Figure 3b, the number of reviewed research articles per investigated country is illustrated. Considering the riparian countries of the Amazon river basin, we found that the number of studies is highest for Brazil (e.g., [34-37]). Although river basins are a functional unit regardless of national boundaries, Figure $3 \mathrm{~b}$ clearly indicates areas of special interest. With more detail, these include China, Brazil, Vietnam, and the United States of America, where the percentage of studies amounts to $~ 29 \%$, $\sim 21 \%, \sim 11 \%, \sim 8 \%$, respectively. For several major river basins, such as the Niger, Nile, Zambezi, and Danube, it becomes apparent that the territory of some countries included in the functional unit of the river basin remained entirely unstudied.

In this framework, Figure 4 describes the institutional affiliation of the first authors of all reviewed research articles. Here, an alignment of the number of institutional affiliations and the number of reviewed studies per investigated country is noticeable (see Figure $3 \mathrm{~b}$ and Supplement Table S1). We figured that studies conducted by first authors affiliated to China also dealt with study areas located in China in $\sim 89 \%$ of the investigations. In case of Brazil, the corresponding percentage amounts to $\sim 75 \%$. First authors associated with Germany mostly investigated study areas located in Asia ( $\sim 85 \%)$. Moreover, first authors affiliated with the United States of America dealt with study areas 
located on the American continent in $\sim 60 \%$ of all studies. It must be noted that regarding institutional affiliations of co-authors, $\sim 42 \%$ of all reviewed studies are conducted by cross-border collaborations.

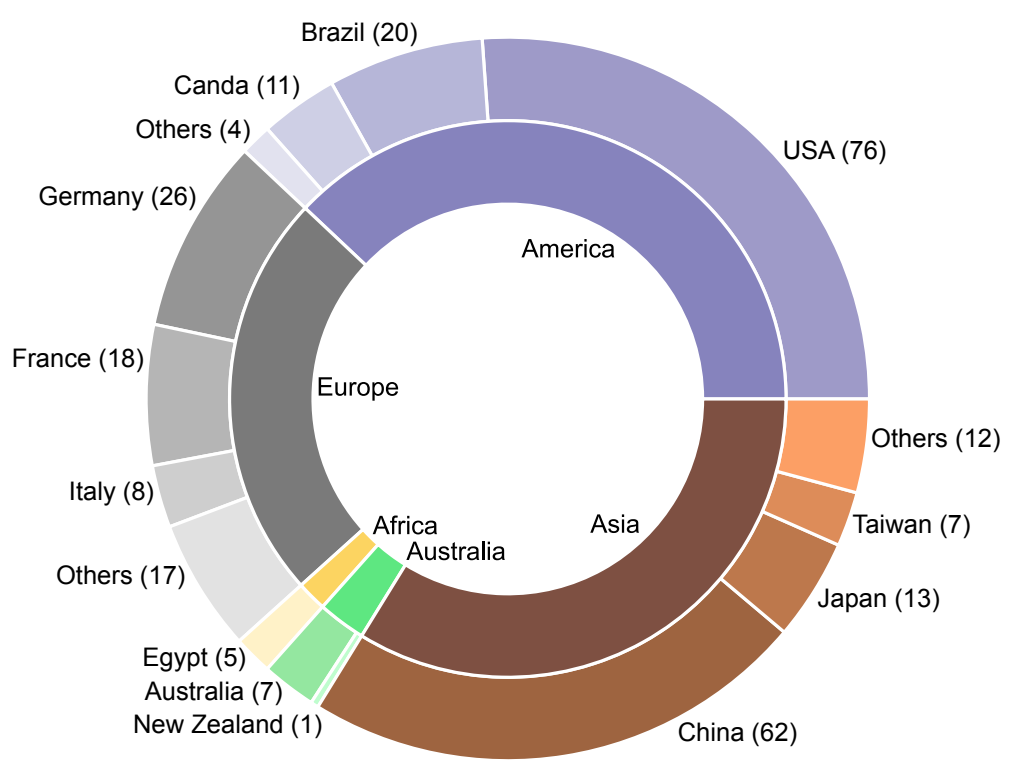

Figure 4. Institutional affiliation of first authors by continent and nation. The number of reviewed studies is provided in brackets.

\subsection{Broad Categorization of Research Foci}

During literature review, we categorized all research articles into "biosphere", "hydrosphere", and "cryosphere". According to these spheres, we identified research foci as sub-categories describing EO-based quantification of land surface and surface water parameters (see Table 2 and Figure 5). With a share of $\sim 53 \%$, the research category biosphere was studied in more than half of the reviewed investigations. Within this category, the main research focus was on vegetation characteristics ( $\sim 39 \%)$. Following this, multi-class land cover and land use classifications were studied in $\sim 32 \%$ of all investigations (Figure 5). Studies associated with the research foci "urban", "agriculture", and "coastline" amount to a share of $\sim 12 \%, \sim 12 \%$, and $\sim 5 \%$, respectively. On the other hand, the research category hydrosphere was studied in $\sim 39 \%$ of all reviewed articles. This category includes research foci related to the quantification of surface water and river characteristics. Here, the topic "surface water" had the highest share of articles $(\sim 45 \%)$. These studies primarily focused on binary surface water extent classification as well as on the quantification of flooding and inundation dynamics. Finally, investigations related to river properties such as "water quality", "river water level", and "river discharge" amount to $\sim 27 \%, \sim 16 \%$, and $\sim 12 \%$, respectively. In comparison, the category cryosphere included $\sim 8 \%$ of the reviewed research articles. Here, we identified "snow and ice cover", "permafrost", and "river and lake ice" as research foci. 


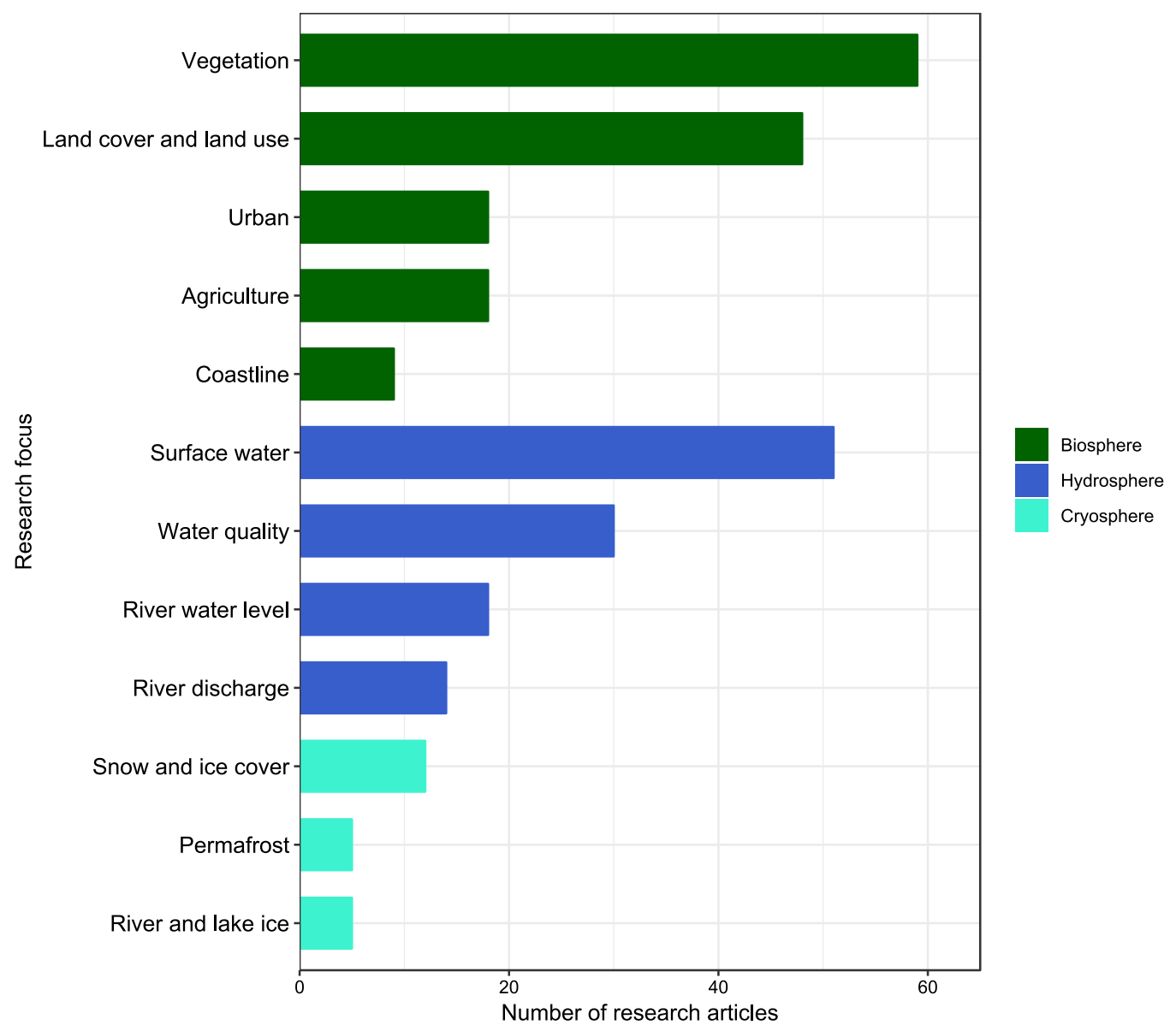

Figure 5. Number of reviewed research articles per research focus.

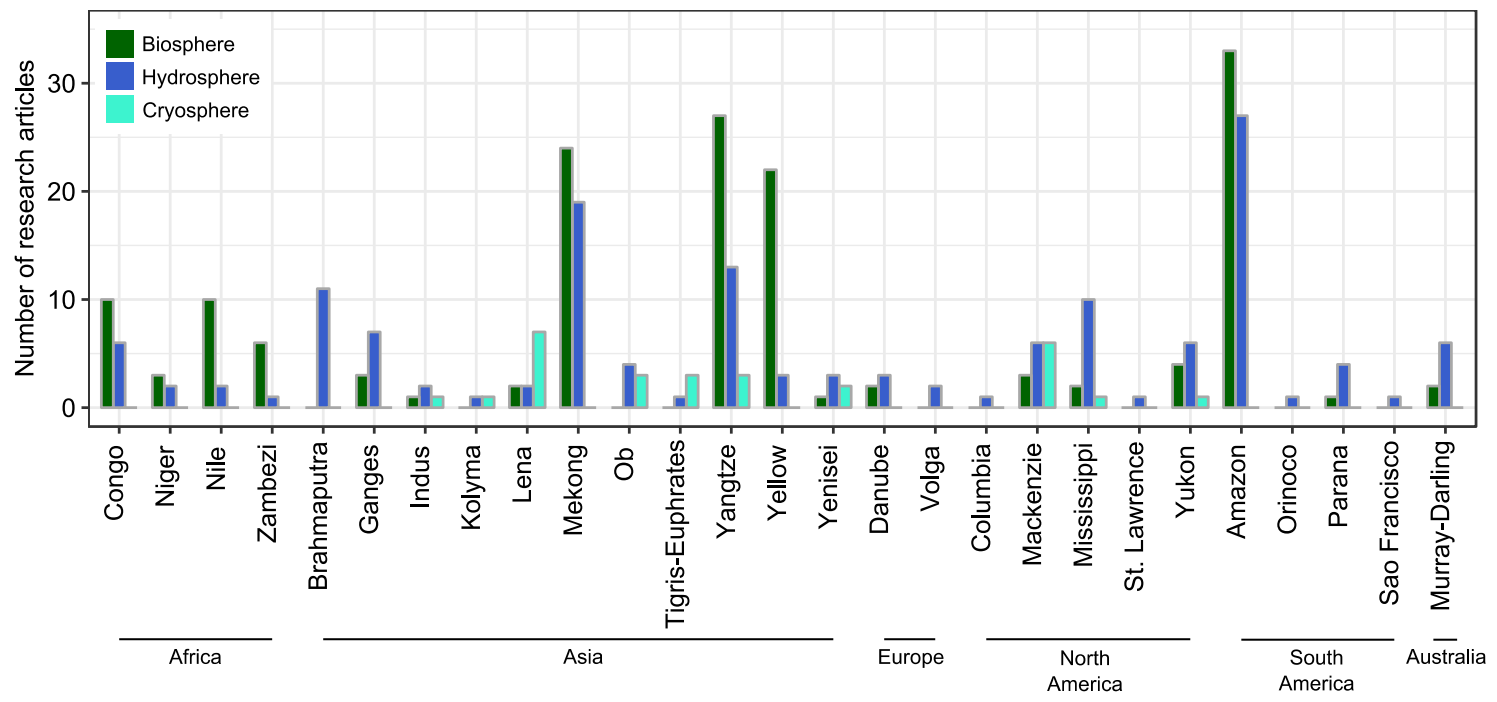

Figure 6. Number of reviewed research articles categorized by major river basin and research category.

Figure 6 presents the number of reviewed research articles with respect to one of the defined research categories per investigated major river basin. This figure indicates that Arctic river basins as well as several river basins with highly mountainous source regions, such as the Indus and Tigris-Euphrates, have a comparably higher share of studies associated with the category cryosphere. In the case of the Brahmaputra, Columbia, Orinoco, Sao Francisco, St. Lawrence, and Volga river 
basins, all reviewed articles investigated research foci related to the hydrosphere. Yet, the total number of reviewed articles is comparably low for these river basins. Furthermore, for the Amazon, Congo, Mekong, Yangtze, and Yellow river basins, the category biosphere accounted for more than half of all studies in each individual river basin.

\subsection{Employed Sensor Types in Reviewed Research Articles}

In terms of used sensor types within the studies, we found that imagery recorded by optical sensors were most frequently used (see Figure 7 ). Specifically, $\sim 61 \%$ of all studies rely solely on optical remote sensing data. Furthermore, $\sim 13 \%$ of all studies only used SAR and $\sim 6 \%$ altimetry data. Optical and SAR data are most frequently combined $(\sim 5 \%)$, while synergistic use of optical and passive microwave data accounted for $\sim 4 \%$ of all investigations. Further sensor combinations are visualized in Figure 7 and amount together to $\sim 11 \%$.

Figure 8 visualizes the share of used sensor types with respect to the identified research foci. Similar to the results in Figure 7, optical imagery is the most frequently used data source across all research categories. With more detail, $\sim 14 \%$ of the studies investigating research questions related to vegetation characteristics used optical imagery. Similarly, optical data was the primary data source for studies with their research focus on "land cover and land use" ( 13\%), "urban" ( 5\%), "agriculture" $(\sim 4 \%)$, and "coastline" ( $\sim 3 \%)$. Within the research category biosphere, SAR data was most often used for vegetation mapping $(\sim 5 \%)$.

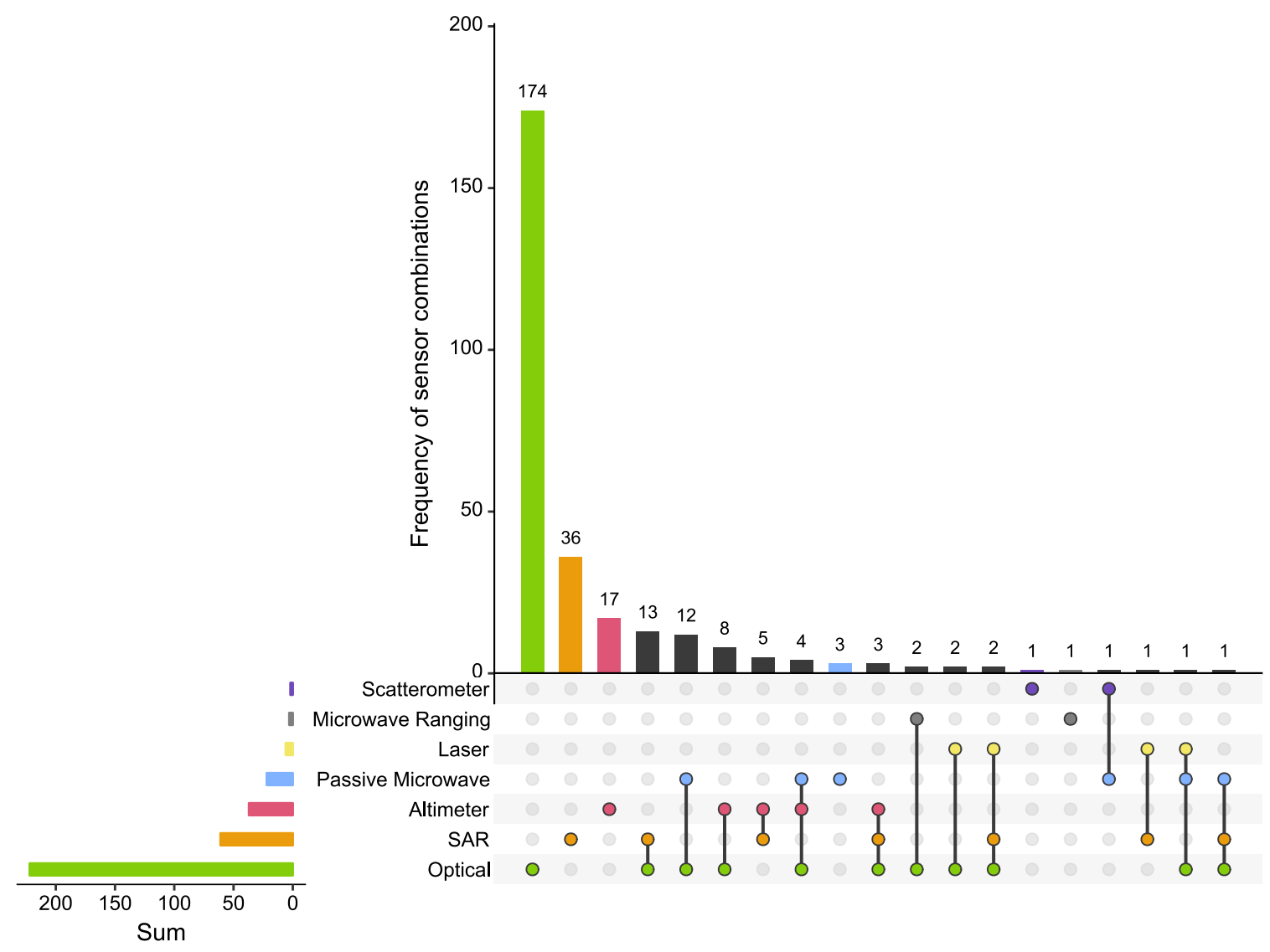

Figure 7. Employed sensor types and their synergistic use in all reviewed articles. 

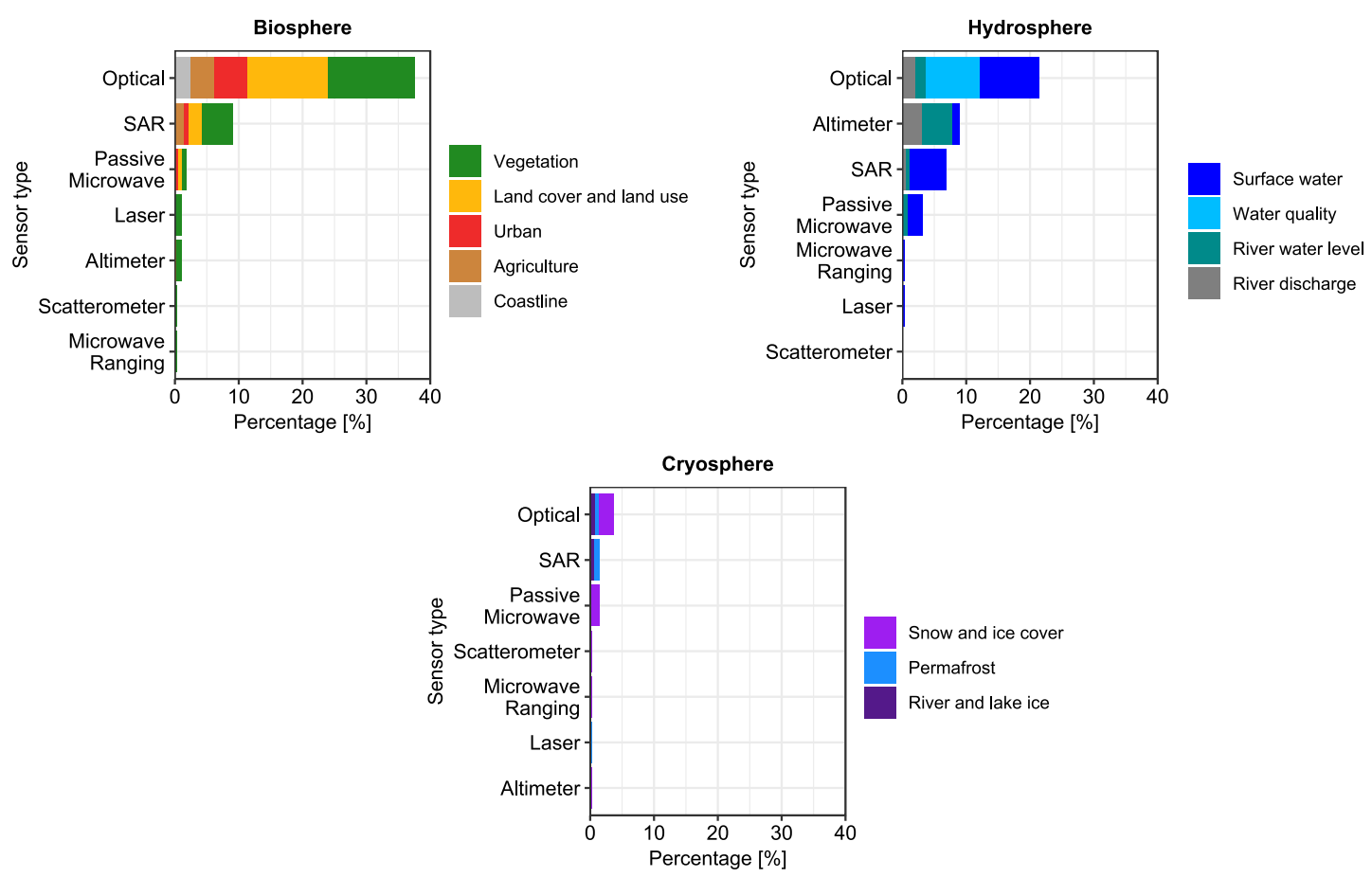

Figure 8. Percentage of employed sensor types categorized by research foci.

Following this, optical imagery was also primarily used for surface water $(\sim 9 \%)$ and water quality ( $\sim 9 \%$ ) mapping. In $\sim 6 \%$ of all studies, SAR images were applied to characterize surface water. Considering river water level and river discharge estimation, altimetry data was used most frequently accounting for $\sim 5 \%$ and $\sim 3 \%$, respectively.

Regarding the research category cryosphere, optical imagery was most often used ( $13 \%)$ for snow and ice $(\sim 2 \%)$ as well as river and lake ice monitoring $(\sim 1 \%)$. Studies focusing on permafrost employed SAR data in most cases $(\sim 1 \%)$.

\subsection{Temporal Resolution of Reviewed Research Articles}

Figure 9 shows the temporal resolution and total observation length of all reviewed investigations. Considering the temporal resolution of the reviewed investigations, we established the classes "single", "intra-annual", and "inter-annual". The class "single" includes all studies performing no change analysis in their results. If the change analysis was conducted at an interval of less than 12 months, we assigned the respective study to the class "intra-annual". The class "inter-annual" comprises all studies conducting a change analysis at an interval greater than a year. In total, we found that $\sim 12 \%$ of all studies performed no change analysis. Furthermore, the results indicate that inter-annual change analyses were undertaken in $\sim 37 \%$ of all reviewed articles, while $\sim 51 \%$ investigated intra-annual changes of a respective parameter. In general, we found that intra-annual investigations considered shorter time periods than inter-annual change analyses. The maximum study period for intra-annual analyses amounts to 29 years and to 56 years for inter-annual analyses. Over the two investigated decades, the number of studies performing no change analysis remained constant (Figure 9a). There is a remarkable increase in the number of studies undertaking intra-annual change analyses starting in 2009. Similarly, we also detected an increase with respect to inter-annual change analysis. 


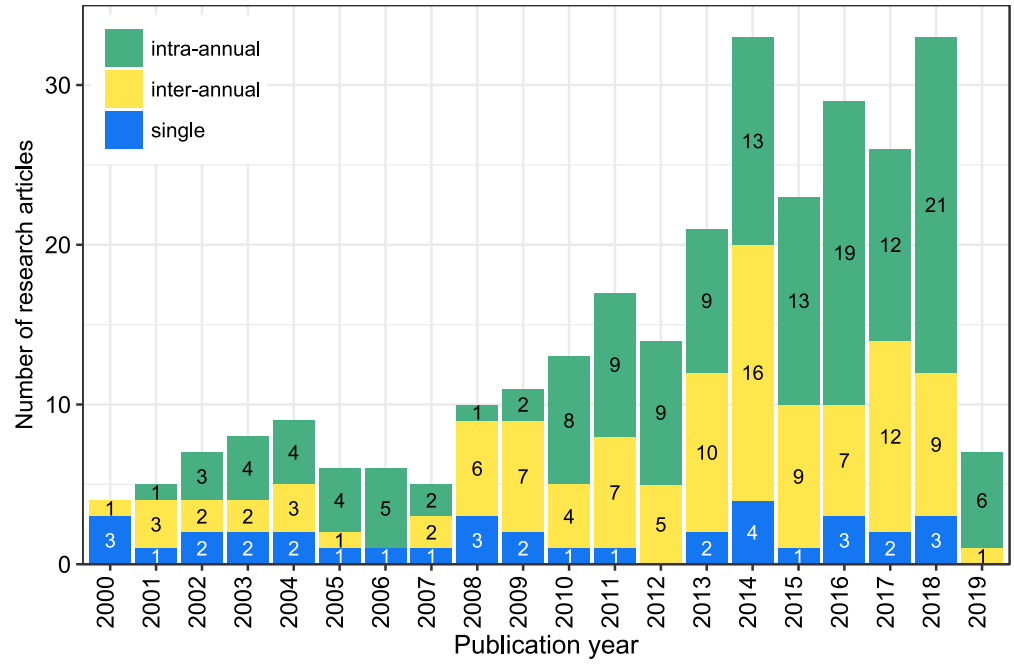

(a)

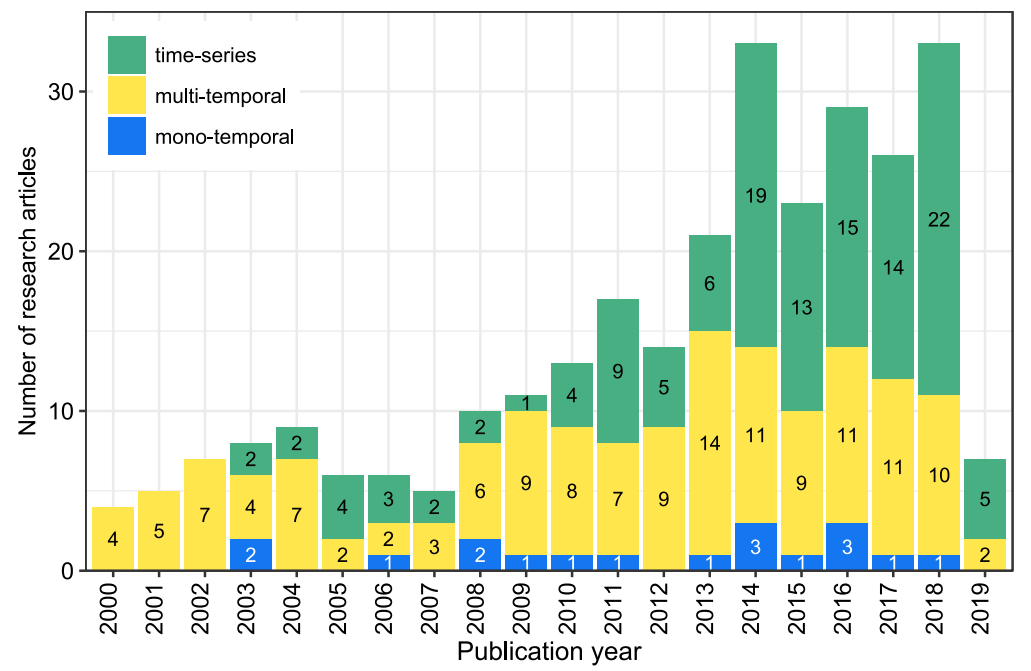

(b)

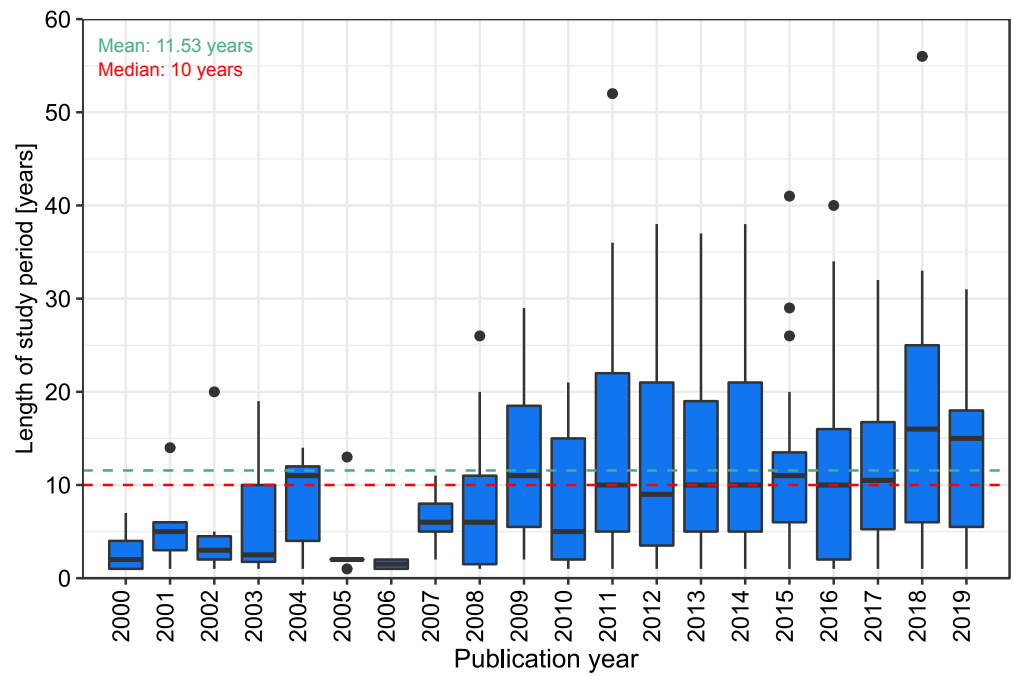

(c)

Figure 9. Number of published studies per year and their temporal resolution with respect to (a) change detection analyses and (b) employed satellite imagery. The boxplots demonstrate the (c) length of the study periods of all reviewed articles per publication year. 
In addition, we categorized the studies with respect to the temporal resolution of the employed satellite imagery. Here, we differentiated between "mono-temporal", "multi-temporal", and "time-series" analyses. The first class includes studies that only used single acquisitions and the second class includes investigations that used multiple images at several time steps. The third class "time-series" includes studies where a series of images was used at a constant revisit time and/or the research objective was to perform a trend analysis. The results show that only $\sim 6 \%$ of all considered studies applied single acquisitions as input. In comparison, $\sim 49 \%$ of all reviewed articles used multi-temporal imagery and satellite image time-series were employed in $\sim 45 \%$ of all cases. The distribution of the classes over the two investigated decades is depicted in Figure $9 \mathrm{~b}$. It is noticeable that the number of time-series applications increased consistently since 2011. This also aligns with the identified increase in intra-annual change analyses (see Figure 9a). Corresponding to the increase of the total number of published articles, there was also a slight increase in the use of multi-temporal satellite images since 2008. The usage of mono-temporal satellite imagery remained constantly low.

Considering the length of the investigated study periods, we identified that $\sim 54 \%$ of all study periods were below or equal to 10 years and $\sim 18 \%$ greater than 20 years. Figure $9 \mathrm{c}$ visualizes the length of the study periods per publication year. In general, this figure indicates an overall increase in the length of study periods.

\subsection{Spatial Scale of Reviewed Research Articles}

Moreover, the reviewed research articles were categorized according to the spatial extent of the investigated study area. In this context, we classified the reviewed articles into "basin", "subbasin", and "regional". Here, investigations at the spatial scale of an entire major river basin are assigned to the class "basin". The category "subbasin" considers functional subsets of a river basin, including e.g., source or mouth regions. Lastly, "regional" describes study areas with no spatial relation to the functional unit of a river basin i.e., studies analyzing single satellite acquisitions only. However, these studies still have a clear research focus with respect to one of the selected major river basins.

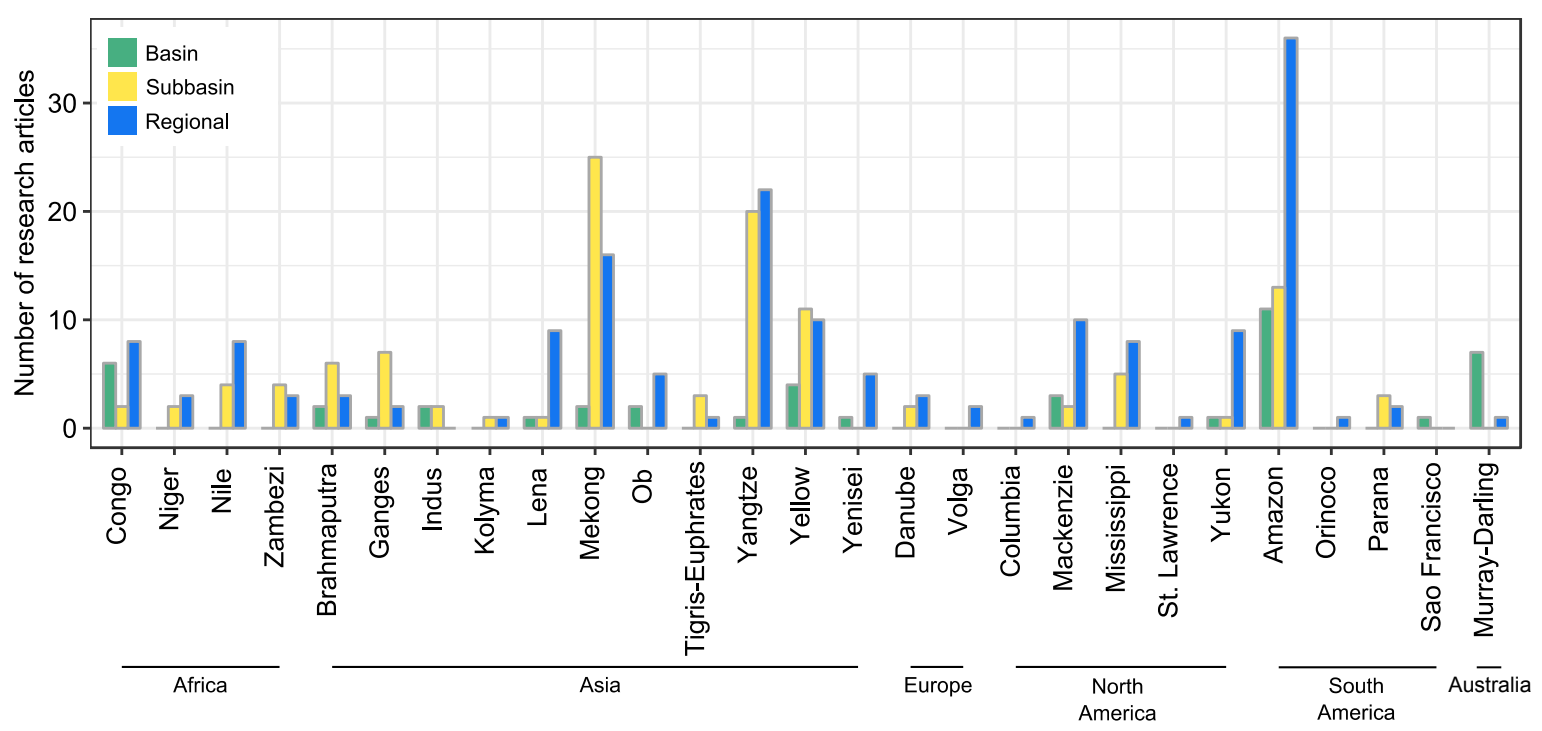

Figure 10. Number of reviewed research articles categorized by major river basin and their investigated spatial scale.

Considering the investigated spatial extent of the reviewed articles in Figure 10, it is evident that the frequency of basin wide studies is comparably low. In total, only $\sim 14 \%$ of the studies focused on the analysis of an entire major river basin and, in comparison, $\sim 37 \%$ of all studies investigated study 
areas at subbasin scale. Almost half of the reviewed studies, specifically $\sim 49 \%$ investigated a study area at regional scale.

With more detail, we found that most of the basin wide applications were conducted for the Amazon river basin $(\sim 4 \%)$. The river basin with the second highest number of basin wide investigations is the Murray-Darling river basin in Australia ( $2 \%)$. Considering the Murray-Darling river basin, almost all available studies are at basin scale. Moreover, the number of studies related to the category "subbasin" is highest for the Mekong, Yangtze, and Yellow river basin. Here, most subbasin analyses had their focus on delta regions. Regional analyses were mostly conducted for the Amazon river basin $(\sim 13 \%)$ as well as for the Yangtze $(\sim 8 \%)$ and Mekong $(\sim 6 \%)$ river basins.

Furthermore, our analysis revealed that most of the reviewed studies focused on the investigation of single river basins only, in particular $\sim 94 \%$ of all articles (e.g., $[15,38,39])$. In $\sim 6 \%$ of all studies, more than one river basin was analyzed (e.g., [40-42]). Additionally, $\sim 69 \%$ of all studies dealt with a transboundary river basin; however, among these studies $\sim 67 \%$ investigated the functional unit of a river basin within one riparian country only.

\subsection{Additional EO-Based Data}

Despite basin wide applications, global geospatial datasets are already available for many land surface parameters. A list of selected layers is presented in Table 3. To our knowledge, the first global land cover dataset was published at a spatial resolution of 1 degree [43]. Later, Loveland et al. [44] used NOAA-AVHRR data, acquired in 1992 and 1993, to generate global land cover data at a spatial resolution of $1 \mathrm{~km}$. Since then, further datasets at even higher spatial and temporal resolution became available. Recently, a yearly global land cover product was published by the European Space Agency's (ESA) Climate Change Initiative (CCI) Land Cover project for the period between 1992 and 2015 and at a spatial resolution of $300 \mathrm{~m}$ [19]. However, global land cover data at high to medium spatial resolution are still lacking. Further layers are available for the parameter vegetation, surface water, and urban areas at global scale. For these thematic datasets, the spatial resolution reaches up to $10 \mathrm{~m}$. Many studies included subsets of global thematic datasets into their analysis. For example, Wang et al. [45] used the global surface water layer to analyze surface water dynamics over the Yangtze river basin. In another study, OSM data was applied to extract built-up areas [20]. Also, MODIS-based land cover products were used in several studies (e.g., [40,46,47]). 
Table 3. Summary of selected open geospatial data sets characterizing land surface and surface water parameters. The temporal resolution is described as yearly $(\mathrm{Y})$, monthly $(\mathrm{M})$, and daily $(\mathrm{D})$.

\begin{tabular}{|c|c|c|c|c|}
\hline Dataset & Data Basis & $\begin{array}{l}\text { Spatial } \\
\text { Resolution }\end{array}$ & $\begin{array}{l}\text { Temporal } \\
\text { Resolution }\end{array}$ & Reference \\
\hline \multicolumn{5}{|l|}{ Land cover } \\
\hline ESA CCI land cover & $\begin{array}{l}\text { ENVISAT-MERIS, } \\
\text { NOAA-AVHRR, } \\
\text { PROBA-V }\end{array}$ & $300 \mathrm{~m}$ & 1992-2015 (Y) & [19] \\
\hline GLC2000 & SPOT & $1 \mathrm{~km}$ & 2000 & [48] \\
\hline MODIS land cover & MODIS & $500 \mathrm{~m}$ & 2001-2013 (Y) & [49] \\
\hline GlobCover & MERIS & $300 \mathrm{~m}$ & 2005,2009 & [50] \\
\hline GlobLand30 & Landsat & $30 \mathrm{~m}$ & $2000,2010(Y)$ & [51] \\
\hline \multicolumn{5}{|l|}{ Agriculture } \\
\hline Global cropland extent & MODIS & $250 \mathrm{~m}$ & $2000-2008$ & {$[52]$} \\
\hline Global map of irrigation areas & multi-source & $5 \mathrm{~km}$ & 2013 & [53] \\
\hline \multicolumn{5}{|l|}{ Vegetation } \\
\hline Global forest change & Landsat & $30 \mathrm{~m}$ & $2000-2018(Y)$ & [54] \\
\hline $\begin{array}{l}\text { MODIS } \\
\text { biophysical parameters }\end{array}$ & MODIS & 250-1000 m & $\begin{array}{l}2000- \\
\text { present }\end{array}(\mathrm{D}, \mathrm{M}, \mathrm{Y})$ & {$[55]$} \\
\hline Copernicus global land service & SPOT-VGT, PROBA-V & varies & varies & (e.g., $[56,57])$ \\
\hline \multicolumn{5}{|l|}{ Urban } \\
\hline $\begin{array}{l}\text { Global human settlement layer } \\
\text { (GSHL) }\end{array}$ & $\begin{array}{l}\text { Landsat, } \\
\text { Sentinel-1 }\end{array}$ & $30 \mathrm{~m}$ & $\begin{array}{l}1975,1990 \\
2000,2014\end{array}$ & [58] \\
\hline Global urban footprint (GUF) & TanDEM-X & $12 \mathrm{~m}$ & 2012 & [59] \\
\hline $\begin{array}{l}\text { World settlement footprint } \\
\text { (WSF) }\end{array}$ & $\begin{array}{l}\text { Landsat, } \\
\text { Sentinel-1 }\end{array}$ & $10 \mathrm{~m}$ & 2015 & {$[60]$} \\
\hline \multicolumn{5}{|l|}{ River properties } \\
\hline Global river network & HydroSHEDS & $500 \mathrm{~m}$ & - & [61] \\
\hline Copernicus water level & Altimeter missions & virtual stations & $\begin{array}{l}\text { 2002- } \\
\text { present }\end{array}$ & {$[62,63]$} \\
\hline \multicolumn{5}{|l|}{ Surface water } \\
\hline Global surface water & Landsat & $30 \mathrm{~m}$ & 1984-2018 (M) & {$[64]$} \\
\hline Global WaterPack & MODIS & $250 \mathrm{~m}$ & $\begin{array}{l}2003- \\
\text { present }\end{array}$ & [65] \\
\hline \multicolumn{5}{|l|}{ Snow cover } \\
\hline Global SnowPack & MODIS & $500 \mathrm{~m}$ & $\begin{array}{ll}2000- \\
\text { present }\end{array}$ & {$[66]$} \\
\hline \multicolumn{5}{|l|}{ Basemaps } \\
\hline TimeScan & Landsat & $30 \mathrm{~m}$ & $\begin{array}{l}2000,2010,(Y) \\
2015\end{array}$ & {$[67]$} \\
\hline Global reservoir and dam v1.3 & multi-source & vector & 2019 & [68] \\
\hline OpenStreetMap & multi-source & vector & present & [69] \\
\hline
\end{tabular}

\subsection{Review of Research Foci}

In this section, a detailed review for the research foci is provided. Here, the review of each research focus is structured based on the spatial scale of the corresponding research articles. Studies at basin scale are reviewed first, followed by studies at regional and subbasin scale.

\subsubsection{Biosphere: Land Cover and Land Use}

Monitoring the state of the Earth's surface is of high importance for quantification of global environmental change. In the context of river basins, data on regional land cover and land use 
characteristics of a river basin act as baseline information for decision-makers and support river basin and water management. We found that $\sim 17 \%$ of all reviewed articles focused on multi-class land cover and land use classifications. Among these, only $\sim 10 \%$ quantified and analyzed land cover and land use at the spatial scale of an entire major river basin [16,70-73]. Here, we found that most of the basin wide land cover and land use studies were conducted for the Yellow river basin. With more detail, Wohlfart et al. [16] quantified land cover change for two time steps, specifically 2003 and 2013, using time-series of MODIS data at a spatial resolution of $250 \mathrm{~m}$. Also, Wang et al. [72] evaluated land cover change for the entire Yellow river basin between the years 1990, 1995, and 2000 by means of Landsat imagery. On the other hand, Matsuoka et al. [71] analyzed land cover for East China, including the whole Yellow river basin. They used MODIS as well as nighttime light imagery for one time step and employed a decision tree classifier. Moreover, land cover of the Mekong river basin was quantified for 2010 by using time-series of MODIS-based vegetation indices for 11 years at a spatial resolution of $500 \mathrm{~m}$ [73]. Here, the authors used phenological metrics to classify land use classes. Another basin wide land cover study was performed for the Amazon river basin [70]. In this study, the authors used a mosaic of JERS-1 imagery of 1995 and mainly focused on vegetation type classification.

On the contrary, $\sim 90 \%$ of the studies within this research focus investigated regional and subbasin scale land cover and land use classification. Here, $\sim 21 \%$ of these studies assessed the state of land cover and land use for a single time step. In particular, regional land cover classifications were generated for the delta regions of the Arctic river basins Lena and Mackenzie [74-76]. Schneider et al. [74], for instance, used multi-temporal Landsat-ETM images recorded in 2000 and 2001 to generate the first land cover classification of the Lena river delta. The authors used the resulting land cover map to quantify methane emissions over the delta region. Ullmann et al. [76] used polarimetric SAR and Landsat-OLI data to conduct a regional land cover classification over the Mackenzie river delta. Due to the Arctic environment in this study, the classes bare ground, tundra vegetation, and wetland areas were of particular interest. Also, Walker et al. [77] presented a hierarchical classification scheme that used optical and SAR, particularly Landsat-TM and ALOS-PALSAR imagery, in a synergistic way to derive a land cover map for a subset of the Amazon river basin. Further studies dealt with the Yellow river delta [78-80]. For example, Liu et al. [78] employed a random forest classifier on a mono-temporal Landsat-OLI acquisition together with derived texture parameters to classify land cover. Next, Guan et al. [79] generated a mono-temporal land cover map combining the classification results based on MODIS and Landsat-OLI imagery. On the other hand, $\sim 79 \%$ of these studies performed regional and subbasin scale land cover and land use change analyses. Here, dam induced land cover change was analyzed particularly often [81-85]. For example, Feng et al. [85] investigated regional land cover change induced by the construction of the Belo Monte dam in the Amazon river basin. In this study, the authors used high and very high spatial resolution multispectral imagery from 4 different sensors, acquired between 2011 to 2016. The results indicated an increase in water body and settlement area, and in contrast, a decrease in bare soil, forest, and agriculture. Furthermore, several studies quantified land cover and land use change for subsets of the Nile river basin using multi-temporal Landsat imagery [86-90]. Abdulaziz et al. [87], for example, found that cropland increased considerably in the East Nile delta region between 1984 and 2003. Similarly, an increase in cropland as well as built-up areas was also detected for the Western Nile Delta [88]. Further studies investigated land cover change on the African continent for the subsets of the Niger [91-93] and Congo river basin [94]. Here, Ruelland et al. [92] performed a land cover classification for a period covering 52 years. In this study, aerial as well as satellite imagery were used to quantify land cover changes. The results indicated an increase in croplands and a decrease in tree cover. Apart from that, many studies examined land cover and land use change for study areas in East Asia, including the Mekong, Yangtze, and Yellow river basin (e.g., [95-99]). In particular, Hu et al. [97] and Ren et al. [98] focused on quantification of aeolian desertification for the source regions of the Yangtze and Yellow river basin. In case of the Yellow river basin, the study period included the years between 1975 and 2005. $\mathrm{Hu}$ et al. [97] found that increasing temperature, overgrazing, and the drainage of wetlands are the 
main drivers behind aeolian desertification. In addition, recently published research articles use the Google Earth Engine (GEE) platform for land cover classifications [20]. Here, the authors applied the random forest classifier on 3 yearly Landsat composites for a regional area of the lower Yenisei river basin over the period of 1985 and 2017. The results of this study revealed a significant change of vegetation cover, particularly infilling of vegetation in tundra and open forests.

\subsubsection{Biosphere: Vegetation}

Considering ecological health, vegetation cover has an important role in river basins. Particularly trees store carbon, regulate surface runoff, and reduce soil erosion in many ways. Overall, $\sim 21 \%$ of all reviewed articles investigated vegetation characteristics. Among these, $\sim 19 \%$ performed basin wide analyses. Here, the Amazon river basin was studied most frequently (e.g., [46,100,101]). For example, de Moura et al. [100] analyzed the response of vegetation to drought events using MODIS time-series as well as further remote sensing-based products, such as precipitation and leaf area index data. Hilker et al. [101] evaluated the usability of MODIS vegetation products to determine changes in vegetation greenness between the years 2000 and 2012. Further studies conducted basin wide analyses for the Congo river basin (e.g., [102-104]). Here, Yan et al. [103] evaluated the impact of the number of good quality observations on the derivation of land surface phenology. For this purpose, they used time-series of SEVIRI and MODIS-based vegetation indices for the period between 2006 and 2013. The results indicated that SEVIRI outperformed MODIS in terms of double annual canopy greenness cycle identification. In a subsequent study, Yan et al. [104] analyzed land surface phenology using SEVIRI data, but also incorporated remote sensing-based precipitation and land cover data. The authors characterized the impact of land cover on the relation between the timing of vegetation greenness and precipitation. According to their findings, the onset of the rainy season has a strong impact on the canopy greenness cycle particularly in regions with lower tree cover, such as shrublands and grasslands. Moreover, basin wide investigations exist for the Murray-Darling and Yellow river basin [15,38]. For instance, Broich et al. [15] used all available Landsat data covering a period of 25 years to study vegetation response to hydroclimatic events such as flooding and drought for the Murray-Darling river basin.

Furthermore, $\sim 81 \%$ of these studies investigated study areas at regional and subbasin scale. Among these, $\sim 27 \%$ of the investigations undertook no change analysis and focused on vegetation type classification for a single time step. Here, most studies dealt with the Amazon river basin and particularly forest type (e.g., [105-107]) as well as aquatic plant classification [108,109]. Further studies estimated mangrove extent for regional study areas in the Mekong and Zambezi river basin [110-112]. Instead, $\sim 73 \%$ of all regional and subbasin scale studies conducted change analyses. A common research objective was monitoring of forest disturbance i.e., caused by deforestation in the Amazon river basin (e.g., [113-116]). To this aim, most studies employed multispectral Landsat imagery. In addition, Yoshikawa and Sanga-Ngoie [116] used NOAA-AVHRR imagery at low spatial resolution to map deforestation between 1981 and 2001. Incorporating data on transportation infrastructure, the authors showed that most of the land cover transformations occurred in close distance to these infrastructures. In comparison, Leinenkugel et al. [117] analyzed deforestation patterns in the Mekong river basin by means of MODIS and Landsat imagery as well as ancillary data on transportation infrastructure. Similar to the aforementioned study, the authors found that deforestation was higher in locations closest to roads. Apart from that, forest disturbances were also caused by fire as investigated for the Yukon river basin [118,119]. For example, Huang et al. [118] evaluated land surface change induced by fire events using Landsat-based normalized difference vegetation index (NDVI), albedo, and land surface temperature. In addition, several studies quantified vegetation cover changes with specific focus on the source regions of the Mekong, Yangtze, and Yellow river basins (e.g., [39,120,121]). These studies used MODIS as well as SPOT-VGT data at low spatial resolution together with meteorological measurements. Liang et al. [120] used MODIS NDVI together with DEM and meteorological data. They identified an increase in vegetation cover with increasing precipitation in high, unpopulated 
elevations as well as vegetation degradation close to human settlements in the source region of the Yellow river basin. In comparison, Ge et al. [39] observed an increase in grassland cover between the period 2001 and 2016. Moreover, Liu et al. [121] analyzed spring phenology for the source region of the Mekong, Yangtze, and Yellow river basin using a SPOT NDVI time-series covering 15 years. Their results showed a significant trend in the advancement of the greening date. This trend correlates highly with elevation. Moreover, several research articles studied vegetation changes for study areas in the Zambezi river basin (e.g., [122-124]). Shapiro et al. [123], for instance, classified mangrove extent for the Zambezi delta region for the years 1994, 2000, and 2013 using Landsat data. Accordingly, they detected a net increase of mangrove forest extent in inland regions. In addition, Bunting et al. [124] analyzed vegetation change using a time-series of GIMMS3g NDVI at a spatial resolution of $8 \mathrm{~km}$ and covering 29 years together with meteorological data. The authors identified changes in soil moisture due to increasing temperatures as well as changes in vegetation greening patterns.

\subsubsection{Biosphere: Agriculture}

In addition, $\sim 6 \%$ of all reviewed studies focused on agricultural applications. To our knowledge, there is no research article analyzing research objectives in this context at basin wide scale. Yet, we found that $\sim 77 \%$ of all regional and subbasin scale studies dealt with study areas in the Mekong river basin. The majority investigated research objectives related to rice crop mapping, in particular classification of rice cropping systems (e.g., [125-127]). Most of these studies used optical imagery, such as MODIS or Landsat. For example, Son et al. [125] derived rice cropping systems using a phenology-based classification approach. To this aim, they employed time-series of MODIS imagery at a spatial resolution of $500 \mathrm{~m}$. In comparison, Kontgis et al. [126] used stacks of multi-temporal Landsat images for 2000 and 2010 together with an object-based decision tree classifier to analyze changes in rice cropping systems. Furthermore, Nguyen et al. [127] mapped rice fields and cropping systems in the Mekong delta using ENVISAT-ASAR time-series over a period of 5 years. Apart from the classification of rice cropping systems, Clauss et al. [128] estimated rice field extent by means of Sentinel-1 time-series and a decision tree classification approach. In a subsequent study, Clauss et al. [129] retrieved rice production estimates based on Sentinel- 1 time-series and national census data. Moreover, we found three studies dealing with the Amazon, Nile, and Yangtze river basin [130-132]. For instance, Shi and Huang [132] classified rice field extent for the Yangtze river delta using 11 years of MODIS images at a spatial resolution of $500 \mathrm{~m}$. Additionally, Xu et al. [131] mapped cropland change for a regional study area including the Nile river delta over a period of approximately 31 years using Landsat imagery. According to their study, a constant increase in cropland area was observed.

\subsubsection{Biosphere: Urban}

Urbanization is one of the most prevalent land use conversions and leads to an increase of impervious surfaces and thus decrease of water permeability. Hence, urban areas are particularly vulnerable to hydrological extreme events including floods. The reviewed studies $(\sim 6 \%)$ investigating urban extent classification, urban growth analyses, and impervious surface area mapping merely focus on regional and subbasin scale study areas in China, specifically the Yangtze and Mekong river basin. With more detail, $\sim 65 \%$ of these articles conducted their studies over the Yangtze river delta and $\sim 29 \%$ for regional study areas in the Middle or Lower Yangtze river basin. Here, one of the research objectives was the analysis of the urban heat island effect [133,134]. In particular, Zhou et al. [134] quantified surface urban heat island intensity using MODIS imagery between 2010 and 2015. Contrary to previous assumptions, the results demonstrated that the intensity of the urban heat island effect was not highest in highly urbanized cities such as Shanghai. Additionally, the authors stated that urban heat island intensity largely depends on climate, solar radiation, and vegetation activity. Following this, Yao et al. [135] evaluated the impact of urbanization on vegetation condition. For this purpose, they used nighttime light data acquired by the DMSP-OLS sensor and MODIS land cover information covering a period of 16 years. The authors extracted urban areas and performed a trend analysis 
on the enhanced vegetation index (EVI) as well as the urban heat island layer. The results indicated significant negative trends of EVI for nearly all the study areas within the Yangtze river basin. On the other hand, a significant positive trend of the urban heat island effect was detected for the study areas. Further studies also employed DMSP-OLS data to quantify urban growth [136-139] and impervious surface area $[140,141]$. Xiao et al. [136], for example, analyzed urban growth for a period of 30 years based on nighttime lights, NOAA-AVHRR, and SPOT NDVI data at a spatial resolution of $1 \mathrm{~km}$. Moreover, Liu and Chen [142] evaluated urban growth for the middle Yangtze river basin. The authors used MODIS and Landsat data for the years 2000, 2008, and 2016. The results indicated that urban areas experienced a considerable growth in terms of area, specifically small and medium sized cities. In comparison, Shao and Liu [140] retrieved impervious surface area and its temporal dynamics from MODIS and DMSP-OLS nighttime lights data at a spatial resolution of $1 \mathrm{~km}$. With respect to the Mekong river delta, Leinenkugel et al. [143] derived a binary settlement mask using TerraSAR-X data, whereas the impervious surface area was derived with SPOT-5 imagery.

\subsubsection{Biosphere: Coastline}

Sediment load of rivers is important with respect to the environmental condition of estuarine regions. Human-induced modifications of river flow might tremendously alter sediment transportation and affect the development of delta regions. In this context, the evolution of coastlines was analyzed in $\sim 3 \%$ of all reviewed studies at regional and subbasin scale including the Mississippi [144], Nile [145,146], Yangtze [147-149], and Yellow river basin [150-152]. Among these, Amer et al. [144] studied the Mississippi river delta which is facing a land loss due to various drivers such as sea level rise or wave erosion. In detail, they used Landsat-based modified normalized difference water index (NDWI) for the years 2000 and 2015. Moreover, Hereher [146] analyzed the evolution of the Nile river delta using Landsat images between 1973 and 2008 to find that coastal area experienced severe erosion affecting approximately $12 \mathrm{~km}^{2}$. In addition, Qiao et al. [149] focused on the Yangtze river delta and quantified coastline dynamics for a period of 55 years. To this aim, they classified the shoreline in 5 year intervals using historical aerial and Landsat imagery. The authors identified that accretion was the dominant process over the delta region. Further on, Kong et al. [152] analyzed the evolution of the Yellow river delta using Landsat data between 1983 and 2011. They quantified the impact of river discharge and sediment load on the delta region and found that the amount of land increased by $248 \mathrm{~km}^{2}$ within the study period.

\subsubsection{Hydrosphere: Surface Water}

Surface water monitoring is important for quantification of the availability of water resources and mitigating impacts of hydrological as well as climatic extreme events. Estimation of surface water extent is possible using optical (e.g., [34]) and active (e.g., [153]) as well as passive (e.g., [154]) microwave sensors. According to our analysis, surface water dynamics were investigated in $\sim 18 \%$ of all reviewed articles. Among these, $\sim 22 \%$ were at basin wide scale and performed change analysis. Here, the investigated study areas included the Amazon [155], Congo [156], Indus [157,158], Murray-Darling [23,159-162], and Yangtze river basin [163] as well as several Arctic river basins [40]. For example, Chapman et al. [155] used ALOS-PALSAR ScanSAR data acquired between 2006 and 2010 covering the entire Amazon river basin to classify open water and inundated vegetation extent. Their results indicated that L-band ALOS-PALSAR ScanSAR data was insensitive to inundated herbaceous vegetation. In case of the Indus river basin, Khan et al. [157] simultaneously used MODIS and ENVISAT-ASAR imagery to map inundation extent, specifically for the flooding event in 2010. Additionally, TRMM-based rainfall estimates and AMSR-E brightness temperature was incorporated to quantify precipitation and streamflow patterns. Similarly, Kwak et al. [158] mapped inundated areas during the Indus flood event of 2010 applying a rule-based approach using a modified land surface water index based on MODIS and SRTM data. Moreover, Du et al. [40] derived fractional water for the entire Arctic region, including the Mackenzie, Yukon, Lena, Yenisei, and Ob river basins 
using multi-source remote sensing data, comprising AMSR-E brightness temperature and land surface parameters as well as MODIS land cover product. Here, surface water dynamics were estimated at a spatial resolution of $5 \mathrm{~km}$ and a temporal resolution of 10 days. Apart from that, Huang et al. [23] developed an approach to classify inundation dynamics by integrating gauge measurements and MODIS imagery for the Murray-Darling basin between 2001 and 2010. To this aim, the authors determined river flow peaks to select and analyze corresponding MODIS imagery using the open water likelihood algorithm [164]. The inundation maps were computed at a spatial resolution of $500 \mathrm{~m}$ and validated against Landsat images. Furthermore, the authors aggregated single inundation maps to annual maps and quantified yearly inundation frequencies. In comparison, Tulbure et al. [161] mapped inundation dynamics for the Murray-Darling river basin using Landsat data for a period of 26 years. According to their results, climatic extremes such as dry and wet periods have a high impact on the surface water dynamics. In a further study, Heimhuber et al. [162] performed an integrated analysis using water masks derived from 26 years of Landsat data [161] as well as precipitation, evapotranspiration, soil moisture, and in situ discharge measurements to model inundation extent dynamics over the Murray-Darling river basin.

On the other hand, $78 \%$ of all studies with focus on surface water parameters analyzed regional and subbasin scale study areas. Here, a number of the reviewed studies investigated inundation dynamics in wetlands (e.g., [25,47,165]). For example, Yuan et al. [47] estimated wetland water level and inundation dynamics for a subset of the Congo river basin using ALOS-PALSAR imagery between the years 2002 and 2011. Since the SAR backscattering signal of ALOS-PALSAR imagery was affected by volumetric scattering caused by vegetation cover, the authors also included ENVISAT-RA2 altimeter data and the MODIS vegetation continuous fields product in their investigation. On the contrary, Wilusz et al. [165] mapped monthly wetland inundation in the Sudd wetland region. For this purpose, they analyzed monthly time-series of ENVISAT-ASAR data at $1 \mathrm{~km}$ spatial resolution over a period of 5 years. In addition, further studies carried out analyses in the context of wetlands using JERS-1 imagery, which were acquired in the framework of the "Global Rain Forest Mapping" (GRFM) project (e.g., [166,167]). Moreover, several studies observed inundation dynamics in delta regions (e.g., [41,168-170]). For example, Sakamoto et al. [168] used MODIS time-series to quantify annual inundation extent over 6 years for the Mekong river delta. Next, Gstaiger et al. [169] developed a threshold-based approach to generate a binary water mask using SAR imagery at different spatial resolutions from the TerraSAR-X, RADARSAT-2, and COSMO-SkyMed sensors. Following this, Kuenzer et al. [170] analyzed patterns of inundation in the Mekong river delta using a time-series of 60 ENVISAT-ASAR scenes at a spatial resolution of $150 \mathrm{~m}$ and covering the period between 2007 and 2011. In another study, the effectiveness of daily MODIS time-series for intra-annual monitoring of inundation dynamics was evaluated for the Mekong, Ganges-Brahmaputra, Mackenzie, and Yellow river deltas [41]. Moreover, several studies performed surface water classification using Landsat imagery (e.g., [45,171-173]). In this framework, Du et al. [171] used a dynamic thresholding approach to derive binary surface water extent maps for a regional study area within the Yangtze river basin. In detail, they used Landsat data for 15 time steps between 1973 and 2010. Here, the authors identified that changes in surface water extent were mostly induced by constructed dams. Furthermore, Li et al. [172] quantified the performance of 11 different NDWI to classify surface water extent using multi-source multispectral imagery, including Landsat-TM, Landsat-ETM, and EO-1 Advanced Land Imager (ALI). The results indicated that ALI-based NDWI using green and SWIR bands resulted in highest accuracies. Furthermore, Wang et al. [45] developed an approach to evaluate surface water dynamics in the middle Yangtze river basin between 1990 and 2017. To extract yearly minimal and maximal surface water extent, Landsat images were processed using the GEE platform. The results were then compared to the JRC global surface water layer indicating comparable surface water extents. In a further study, multispectral imagery, specifically Planet imagery from the RapidEye and PlanetScope sensors were used to quantify the capability of the sensors to derive surface water extent dynamics [174]. These multispectral sensors provide imagery at high spatial resolution and a 
high revisit time; however, limiting factors were automatic cloud masking, inconsistent radiometric calibration, and geolocation errors.

\subsubsection{Hydrosphere: Water Quality}

Human-induced land use conversions put high pressure on water ecosystems. In this context, it is important to monitor the impact of such processes on water quality. In the framework of water quality monitoring, it can be distinguished between estimation of water clarity or turbidity and chlorophyll concentration as well as suspended sediment concentration and organic matter. These features can be measured using optical sensors. Accordingly, all reviewed studies ( $\sim 10 \%)$ applied multispectral imagery and performed analyses at regional and subbasin scale, expect for one study covering the Amazon river basin [175]. Among these studies, $\sim 30 \%$ dealt with an estimation of water color, more specifically turbidity (e.g., [176-179]). Here, Massicotte et al. [176] analyzed the spatial and temporal dynamics of water color at the St. Lawrence river using Landsat-TM/-ETM imagery over a period of 25 years. In fact, they found a significant decrease in the reflectance of the river between 1984 and 2009, potentially caused by land use changes. In a further study, the impact of the Three Gorges dam on water clarity of the Yangtze river was evaluated [178]. To this aim, in situ Secchi disk depth, being a water clarity measure, and further spectral measurements were used together with Landsat-OLI imagery. The results of this study indicated that water clarity of the Three Gorges reservoir and Dongting lake was mainly influenced by total suspended matter.

On the contrary, $\sim 70 \%$ of the reviewed studies dealt with an estimation of sediment concentration or organic matter (e.g., [180-183]). For example, Fassoni-Andrade and de Paiva [183] predicted surface suspended sediment concentration for the Central Amazon river basin, in particular for surface water of rivers and floodplain lakes. They were the first to use a 15 year long time-series of MODIS data to investigate spatial and temporal dynamics of sediment concentration for areas characterized by different water types in the Amazon river basin. Following this, Park and Latrubesse [184] analyzed suspended sediment concentration in the confluence of the Solimões-Amazon and Negro rivers, characterized by white and black water, respectively. For this purpose, the authors used a time-series of MODIS 8-day composites over a period of 14 years. With more detail, suspended sediment concentration and surface water types were modeled for the post-confluence area for three selected years under average, drought, and flood hydrological condition. The authors concluded that surface water mixing patterns along the main channel mainly depend on the hydrological season. Furthermore, several studies investigated water quality impacted by urban areas and mining activities (e.g., [21,185,186]). Lobo et al. [21], for example, analyzed water turbidity in a subbasin of the Amazon river basin for the period between 1973 and 2013 using Landsat-MSS/-TM/-OLI imagery. They estimated suspended sediment concentration and evaluated the results in the context of gold mining activities. The results demonstrated that during high water level, sediment concentration is low. In comparison, during low water level periods, mining activities intensified, and sediment concentration increased. Moreover, Zhu et al. [32] used EO-1 Hyperion imagery to estimate colored dissolved organic matter for 10 major rivers around the globe. For this purpose, the authors used an algorithm, tailored to water conditions in coastal regions. In addition, dissolved organic matter is estimated for 6 Arctic river basins using Landsat imagery over a period of 14 years [31]. Here, a regression-based method is used to derive organic matter using field samples along with Landsat imagery. The correlation coefficient between estimated and measured dissolved organic matter accounted for 0.67 to 0.84 for most of the study areas.

\subsubsection{Hydrosphere: River Water Level}

Measurements of river water level are important for quantification of water storage and assessment of risks related to droughts and floods [187]. Here, EO-based monitoring of water level provides consistent measurements of remote and large river basins. These measurements are performed by spaceborne altimetry at satellite ground track, also called virtual gauge stations. Since satellite 
altimeters illuminate footprints at a certain diameter, land and water signals are mixed. Thus, EO-based water level measurements of small water bodies or rivers are challenging [188,189].

In the context studies related to river water level, most investigations are conducted for the Amazon (e.g., [190-192]), Brahmaputra (e.g., [193,194]), Congo (e.g., [195,196]), Ganges (e.g., [197,198]), and Mekong river basin (e.g., $[199,200])$. Among these, $~ 33 \%$ of the studies retrieved river water level for virtual stations distributed over the entire river basins and the remaining studies for virtual stations at regional and subbasin scale only. For example, da Silva et al. [191] used ERS-RA and ENVISAT-RA2 altimeter data to predict river water level at 45 virtual stations. The authors performed an internal and external validation using crossovers of altimeter tracks and gauge measurements, respectively. The results of the validation indicate high variations for the root mean square difference, in particular between $12 \mathrm{~cm}$ and several meters. Moreover, Huang et al. [194] developed a novel waveform retracking algorithm called "threshold and Ice-1 combination" for river water level retrieval. This algorithm was particularly proposed for high mountainous areas and tested for the Upper Brahmaputra river basin. The results demonstrate that the suggested algorithm derives more accurate estimations of water level than other retracking algorithms. In a further study, Villadsen et al. [201] used CryoSat-2 altimeter data for river water level estimation over the Ganges and Brahmaputra and evaluated their results with water levels retrieved from ENVISAT-RA2 measurements. CryoSat-2 altimeter data are characterized by a smaller along track footprint enabling measurements of smaller water bodies. The resulting time-series were compared on annual basis and indicated comparable water levels with a reported mean difference of $10 \mathrm{~cm}$ for all virtual stations. Similarly, CryoSat-2 SAR altimeter data are used to retrieve water levels over the Mekong river basin [202]. For validation, ENVISAT-RA2-based water level estimations and gauge measurements were used. Here, the authors obtained a median difference of $0.76 \mathrm{~m}$. Next, Liu et al. [203] performed an integrated analysis using altimeter data from the ENVISAT-RA2 and Poseidon-3 instrument on-board JASON-2 as well as Landsat imagery and TRMM-based precipitation data to quantify downstream water level changes induced by dam constructions at the Mekong river. According to their findings, the water level decreased and increased in wet and dry season, respectively. Furthermore, Pham et al. [200] for the first time used MODIS-based land surface temperature together with JASON-2 altimetry data and in situ water level measurements to estimate daily water level at virtual stations along the Mekong river. In this study, seasonal linear regression models were used to predict water levels. The results indicated that the river water level estimations were best for cold/dry and hot/dry seasons.

\subsubsection{Hydrosphere: River Discharge}

Considering the forecasting of extreme events such as floods, river discharge is an essential parameter to study. Traditionally it is measured at in situ gauge stations; however, these networks are scarce in many regions. Accordingly, estimation of river discharge is possible using indirect EO-based approaches [204]. Regarding river basins, studies are performed the Amazon [205,206], Brahmaputra [207,208], Congo [209], Mekong (e.g., [210,211]), and Yangtze river (e.g., [212]). Here, common methods to retrieve river discharge are rating curves (e.g., [213]) or the Manning's equation (e.g., [214]). In this context, Paris et al. [205] formulated rating curves based on river water level derived from altimeter data over the entire Amazon river basin for around 1000 virtual stations. Corresponding discharge simulations are predicted by a rainfall-runoff model. A comparison of the predicted discharge with in situ observations resulted in a Nash-Sutcliffe efficiency of 0.71. Moreover, Dubey et al. [207] retrieved water level based on TOPEX-Poseidon and ENVISAT-RA2 data for 6 virtual stations along the Brahmaputra river between the years 2002 and 2010. The rating curves were developed based on estimated water level and in situ discharge observations. This relationship was then used to predict discharge at virtual stations. The resulting discharge estimations indicated high correlations with observed discharge. In addition, Kouraev et al. [215] applied rating curves as well. Here, the authors retrieved TOPEX-Poseidon-based water level for the Ob river and related it to discharge observations at a gauge station. Observed and estimated river discharge 
indicated good agreement; however, due to the spatial resolution of TOPEX-Poseidon measurements, the proposed approach is only applicable to rivers with a width of several kilometers. Furthermore, Huang et al. [208] aimed at river discharge estimation in the Upper Brahmaputra river basin, which is characterized by high mountainous landscape. In this study, 3 algorithms were tested and compared. The first depended on water level, the second on river width, and the third on both variables. Water level was derived using satellite altimeter data and river width was estimated with multispectral and SAR imagery. Here, data processing and discharge estimation was performed on the GEE. The derived water surface extent was validated using high spatial resolution optical imagery. Discharge estimations were compared to observations obtained from gauge stations resulting in a Nash-Sutcliffe efficiency between 0.68 and 0.98 . In a further study, Manning's equation was used to estimate river discharge at 2 virtual stations of the Yangtze river [212]. Here, the hydraulic parameters river width, water level and velocity were derived using remote sensing data only. Specifically, ENVISAT-RA2 was used for water level and MODIS for river width estimations. Given that, velocity was retrieved using time lag analysis of temporal river width observations. The Nash-Sutcliffe efficiency value was 0.5 and 0.76 for the two virtual stations.

\subsubsection{Cryosphere}

The cryosphere, including snow- and ice-covered areas, permafrost, river and lake ice, is mostly an elementary component of river basins, particularly in high-mountain source or Arctic regions. Monitoring dynamics of the cryosphere is important to quantify resulting impacts on downstream or surrounding areas. Due to the limited number of studies in this category, we reviewed all related research foci in one section. With more detail, $\sim 8 \%$ of all studies investigated research questions in the context of the cryosphere, out of which $\sim 14 \%$ at basin wide scale. Among all studies, $\sim 54 \%$ dealt with snow and ice cover (e.g., [216-220]). Chao et al. [216], for instance, employed altimeter data from GLAS-ICESat to analyze glacier elevation change in the source region of the Yangtze river basin. In fact, they identified a shrinking of the glacier between 2000 and 2009. In comparison, Wang et al. [217] quantified glacier retreat in the source region of the Yangtze river using two Landsat images from 1992 and 2009. Additionally, the authors analyzed dynamics of glacial runoff using in situ discharge data from 1957 to 2009. The results indicated an accelerated glacier melting and a loss in glacier area of around $45 \mathrm{~km}^{2}$. In another study, snow cover variability was evaluated for the same study area using MODIS-based snow cover products between 2000 and 2012 [218]. The analysis showed an increase in snow cover extent, whereas long-term analysis of temperature between 1960 and 2012 indicated an earlier start time and a later end of snow melting. Moreover, we identified several studies that dealt with lake and river ice characterization. These studies were conducted for the Arctic river basins Mackenzie, Lena, Yenisei, and $\mathrm{Ob}$ [221-225]. In particular, river ice breakup dates for these four Arctic rivers were successfully classified using NOAA-AVHRR and MODIS imagery for a period of 10 years [221]. Furthermore, Sakai et al. [223] quantified the applicability of Landsat-TM/-ETM images to monitor floods induced by river ice breakup. Here, the shortening of the Landsat revisit time to 2.6 days was of particular advantage due to the triple overlap of tiles in high latitudes. Instead, lake ice phenology was studied using TerraSAR-X time-series for a period of three years in the Lena river delta [224]. In addition, we found studies investigating permafrost in the Arctic river basins Lena, Yukon, and Kolyma [30,226-229]. Soil erosion in permafrost riverbanks was analyzed for a regional study area in the Lena river delta using TerraSAR-X time-series [227]. In particular, the authors classified changing cliff-top line during summer months between 2013 and 2015. In comparison, Whitley et al. [229] evaluated the advantages of LIDAR and IKONOS data to classify permafrost distribution at a subset of the Yukon river delta. Here, best overall accuracies were obtained for estimations based on LIDAR only. 


\section{Discussion}

\subsection{Requirement of Higher Spatial Coverage}

This review revealed that the analysis of major river basins is mostly limited to regional or subbasin scale study areas (see Section 3.5). In this regard, the spatial coverage of the study areas was mostly defined by national boundaries, instead of the functional unit of a river basin. In fact, this circumstance obviously hampered the analysis of transboundary river basins and is most likely caused by factors, such as research funding or motivation i.e., as indicated by the relation between institutional affiliation of the first authors (Figure 4) and their investigated study areas (Figure $3 \mathrm{~b}$ and Supplement Table S1). Due to the availability of mostly regional or subbasin scale studies, it is difficult to compare or assess land surface changes within or between major river basins. In this context, we found that basin wide studies are overall lacking for all regarded research foci. Indeed, there are no basin wide studies for 12 of the regarded major river basins (see Figure 10). Furthermore, our review also demonstrates that comparisons between major river basins are mostly avoided. Specifically, we only identified a small number of studies investigating multiple river basin at once (e.g., [40,179]). However, more studies and remote sensing products at higher spatial coverage, most preferably at basin wide scale, are needed for consistent and homogenous spatial analyses. Considering the identified research foci, we particularly found that elements of the cryosphere remain understudied as demonstrated in Figure 5. Here, higher spatial coverage analyses are necessary for Arctic river basins, which are particularly vulnerable to accelerating climate change.

\subsection{Requirement of Comparability between Major River Basins}

During the last decade, many global remote sensing products outlining land surface and surface water parameters became available (Table 3). These data are essential for a variety of applications including hydrological, climate, and environmental change modeling. In this context, several data portals, such as the UNEP-TWAP or WRI platform, are available. However, these are mostly not up to date and focus on selected indicators only. Hence, databases gathering relevant state-of-the-art geospatial data with respect to river basin characterization are still lacking. To enable a consistent and detailed analysis of major river basins, a database on global open geodata, including available and relevant EO products is needed. However, we must note that already existing global land cover products are probably not applicable for change analyses at regional scale, since their spatial resolution is too coarse [230]. Thus, basin wide monitoring of land surface dynamics at medium to high spatial resolution is necessary to provide valuable baseline information, e.g., on land cover and land use to support researchers, stake-holders, and decision-makers with respect to river basin and water resource management.

\subsection{Potential of EO for Major River Basins}

Monitoring large-scale river basins, where land surface and surface water are highly variable in space and time, is possible using EO data. Here, the increasing amount of free and open remote sensing imagery as well as improving processing and technological capacities support EO applications for large river basins. In this context, it is noteworthy that characterization of land surface and surface water dynamics using open satellite image time-series at medium to high spatial resolution is only possible since the last decade. Notable missions in this context are the USGS Landsat, European Copernicus Sentinel-1/-2, and several altimetry instruments. According to the increasing abundance of satellite missions and open archives, we detected a considerable increase in intra-/inter-annual change analyses and time-series applications since 2008 (see Figure 9a,b). Additionally, as visualized in Figure 9c, we identified an increase in the length of study periods since 2008. At the same time, our review revealed that these open long-term archives are exploited insufficiently when it comes to basin wide analyses of land surface and surface water parameters. This might be due to mass amounts of EO data that need to be processed for basin wide analyses. In fact, it needs to be considered that 
the technological infrastructure, such as data storage and computing capabilities, might still pose a major challenge for these amounts of data. However, in times of cloud computing, it is possible to partially leave these limitations behind. In the context of large river basins, applications exploiting the potential of EO data and products (Table 3) are lacking and need to be studied by processing and analyzing long-term archives for environmental change monitoring.

\section{Conclusions}

This review provides an extensive overview of EO related research articles with respect to selected major river basins. In particular, we reviewed studies on land surface and surface water parameters with specific emphasis on their (1) spatial distribution, (2) employed sensor types, (3) temporal resolution, (4) spatial scale and (5) presented relevant global remote sensing products. Corresponding to the results of this review, the main findings of this study are summarized considering the research questions defined in Section 1.3:

- During literature review, we identified 287 research articles and defined three main research categories, in particular biosphere, hydrosphere, and cryosphere as well as more detailed sub-categories. In summary, $\sim 53 \%$ of all studies focused on research foci related to the biosphere, $\sim 39 \%$ on the hydrosphere, and $\sim 8 \%$ on the cryosphere. With more detail, the reviewed studies most frequently investigated research foci related to vegetation $(\sim 21 \%)$, surface water $(\sim 18 \%)$, and land cover and land use $(\sim 17 \%)$.

- Throughout all research categories, optical EO data were most frequently used. Here, $\sim 61 \%$ of all studies solely used optical imagery and $\sim 17 \%$ combined optical with other sensor types. In detail, Landsat sensors were mostly employed, specifically in $\sim 43 \%$ of all studies. Following optical sensors, SAR $(\sim 13 \%)$ and satellite altimeters $(\sim 6 \%)$ were the second and third most used sensor type, respectively.

- Considering the spatial scale of the reviewed research articles, we found that studies at basin scale were performed in $\sim 14 \%$ of all studies only. Most of these studies were available for the Amazon river basin. Following this, studies at subbasin and regional scale accounted for $\sim 37 \%$ and $\sim 49 \%$, respectively. In addition, our review revealed that transboundary river basins remain understudied. In particular, $\sim 67 \%$ of studies analyzing transboundary river basins focused on one of the riparian countries only. We also identified a strong relation between investigated study area and the institutional affiliation of the first authors. Moreover, the number of studies incorporating multiple major river basins into their analyses was low $(\sim 6 \%)$.

- Regarding the large scales of major river basins, the availability of accurate and consistent reference data is a major limitation. These are crucial in terms of model training and validation. Furthermore, sensor specific limitations exist with respect to e.g., water level estimation for small water bodies or cloud obstruction for optical sensors. However, we expect an increasing number of studies exploiting data of the current Sentinel-1/-2 and Landsat missions and providing EO products at even higher spatial coverage and resolution in the coming years. In addition, upcoming missions, such as SWOT and P-band Biomass, will enable monitoring e.g., of smaller water bodies and certainly boost applications related to river water level and river discharge modeling as well as improve quantification of wetland areas and inundated forest areas, respectively.

In conclusion, our review for the first time provides a detailed overview of available EO related studies and products analyzing land surface and surface water variables over large river basins. Furthermore, we emphasize the importance and need for a database enabling the joint exploitation of EO data and products to improve environmental change monitoring in the context of river basins. Overall, this review greatly contributes to a better understanding of the potentials and limitations of EO-based major river basin analyses. 
Supplementary Materials: The following are available online at https:/ / zenodo.org/record/3531949, Table S1: References used for systematic review.

Author Contributions: Conceptualization, S.U. and C.K.; writing-original draft preparation, S.U.; writing-review and editing, S.U. and C.K.; visualization, S.U.; supervision, C.K.

Funding: This research received no external funding.

Conflicts of Interest: The authors declare no conflict of interest.

\section{References}

1. Kummu, M.; de Moel, H.; Ward, P.J.; Varis, O. How close do we live to water? A global analysis of population distance to freshwater bodies. PLoS ONE 2011, 6, e20578. [CrossRef] [PubMed]

2. Best, J. Anthropogenic stresses on the world's big rivers. Nat. Geosci. 2018, 12, 7-21. [CrossRef]

3. Gleick, P.H. Water, Drought, Climate Change, and Conflict in Syria. Weather. Clim. Soc. 2014, 6, 331-340. [CrossRef]

4. Hecht, J.S.; Lacombe, G.; Arias, M.E.; Dang, T.D.; Piman, T. Hydropower dams of the Mekong River basin: A review of their hydrological impacts. J. Hydrol. 2019, 568, 285-300. [CrossRef]

5. Anthony, E.J.; Brunier, G.; Besset, M.; Goichot, M.; Dussouillez, P.; Nguyen, V.L. Linking rapid erosion of the Mekong River delta to human activities. Sci. Rep. 2015, 5, 14745. [CrossRef]

6. Grill, G.; Lehner, B.; Thieme, M.; Geenen, B.; Tickner, D.; Antonelli, F.; Babu, S.; Borrelli, P.; Cheng, L.; Crochetiere, H.; et al. Mapping the world's free-flowing rivers. Nature 2019, 569, 215-221. [CrossRef]

7. Vörösmarty, C.J.; McIntyre, P.B.; Gessner, M.O.; Dudgeon, D.; Prusevich, A.; Green, P.; Glidden, S.; Bunn, S.E.; Sullivan, C.A.; Liermann, C.R.; et al. Global threats to human water security and river biodiversity. Nature 2010, 467, 555. [CrossRef]

8. Haddeland, I.; Heinke, J.; Biemans, H.; Eisner, S.; Flörke, M.; Hanasaki, N.; Konzmann, M.; Ludwig, F.; Masaki, Y.; Schewe, J.; et al. Global water resources affected by human interventions and climate change. Proc. Natl. Acad. Sci. USA 2014, 111, 3251. [CrossRef]

9. Vanham, D.; Hoekstra, A.Y.; Wada, Y.; Bouraoui, F.; de Roo, A.; Mekonnen, M.M.; van de Bund, W.J.; Batelaan, O.; Pavelic, P.; Bastiaanssen, W.G.M.; et al. Physical water scarcity metrics for monitoring progress towards SDG target 6.4: An evaluation of indicator 6.4.2 "Level of water stress". Sci. Total Environ. 2018, 613-614, 218-232. [CrossRef]

10. Mekonnen, M.M.; Hoekstra, A.Y. Four billion people facing severe water scarcity. Sci. Adv. 2016, 2, e1500323. [CrossRef]

11. Sheffield, J.; Wood, E.F.; Pan, M.; Beck, H.; Coccia, G.; Serrat-Capdevila, A.; Verbist, K. Satellite Remote Sensing for Water Resources Management: Potential for Supporting Sustainable Development in Data-Poor Regions. Water Resour. Res. 2018, 54, 9724-9758. [CrossRef]

12. De Stefano, L.; Petersen-Perlman, J.D.; Sproles, E.A.; Eynard, J.; Wolf, A.T. Assessment of transboundary river basins for potential hydro-political tensions. Glob. Environ. Chang. 2017, 45, 35-46. [CrossRef]

13. Lehner, B.; Verdin, K.; Jarvis, A. New global hydrography derived from spaceborne elevation data. Eos Trans. Am. Geophys. Union 2008, 89, 93-94. [CrossRef]

14. Alsdorf, D.E.; Rodríguez, E.; Lettenmaier, D.P. Measuring surface water from space. Rev. Geophys. $2007,45$. [CrossRef]

15. Broich, M.; Tulbure, M.G.; Verbesselt, J.; Xin, Q.C.; Wearne, J. Quantifying Australia's dryland vegetation response to flooding and drought at sub-continental scale. Remote Sens. Environ. 2018, 212, 60-78. [CrossRef]

16. Wohlfart, C.; Liu, G.H.; Huang, C.; Kuenzer, C. A River Basin over the Course of Time: Multi-Temporal Analyses of Land Surface Dynamics in the Yellow River Basin (China) Based on Medium Resolution Remote Sensing Data. Remote Sens. 2016, 8, 186. [CrossRef]

17. GRDC. Major River Basins of the World; The Global Runoff Data Centre: Koblenz, Germany, 2019.

18. Center for International Earth Science Information Network, CIESIN, Columbia University, 2018. Gridded Population of the World, Version 4 (GPWv4): Population Count, Revision 11. Available online: https: / / sedac.ciesin.columbia.edu/data/collection/gpw-v4 (accessed on 1 October 2019).

19. Plummer, S.; Lecomte, P.; Doherty, M. The ESA Climate Change Initiative (CCI): A European contribution to the generation of the Global Climate Observing System. Remote Sens. Environ. 2017, 203, 2-8. [CrossRef] 
20. Nyland, K.E.; Gunn, G.E.; Shiklomanov, N.I.; Engstrom, R.N.; Streletskiy, D.A. Land Cover Change in the Lower Yenisei River Using Dense Stacking of Landsat Imagery in Google Earth Engine. Remote Sens. 2018, 10, 1226. [CrossRef]

21. Lobo, F.L.; Costa, M.P.F.; Novo, E. Time-series analysis of Landsat-MSS/TM/OLI images over Amazonian waters impacted by gold mining activities. Remote Sens. Environ. 2015, 157, 170-184. [CrossRef]

22. Sakamoto, T.; Van Nguyen, N.; Ohno, H.; Ishitsuka, N.; Yokozawa, M. Spatio-temporal distribution of rice phenology and cropping systems in the Mekong Delta with special reference to the seasonal water flow of the Mekong and Bassac rivers. Remote Sens. Environ. 2006, 100, 1-16. [CrossRef]

23. Huang, C.; Chen, Y.; Wu, J.P. Mapping spatio-temporal flood inundation dynamics at large river basin scale using time-series flow data and MODIS imagery. Int. J. Appl. Earth Obs. Geoinf. 2014, 26, 350-362. [CrossRef]

24. De Grandi, G.F.; Mayaux, P.; Malingreau, J.P.; Rosenqvist, A.; Saatchi, S.; Simard, M. New perspectives on global ecosystems from wide-area radar mosaics: flooded forest mapping in the tropics. Int. J. Remote Sens. 2000, 21, 1235-1249. [CrossRef]

25. Cao, N.; Lee, H.; Jung, H.C.; Yu, H.W. Estimation of Water Level Changes of Large-Scale Amazon Wetlands Using ALOS2 ScanSAR Differential Interferometry. Remote Sens. 2018, 10, 966. [CrossRef]

26. Tomsett, C.; Leyland, J. Remote sensing of river corridors: A review of current trends and future directions. River Res. Appl. 2019, 35, 779-803. [CrossRef]

27. Grimaldi, S.; Li, Y.; Pauwels, V.R.N.; Walker, J.P. Remote Sensing-Derived Water Extent and Level to Constrain Hydraulic Flood Forecasting Models: Opportunities and Challenges. Surv. Geophys. 2016, 37, 977-1034. [CrossRef]

28. Xu, X.; Li, J.; Tolson, B.A. Progress in integrating remote sensing data and hydrologic modeling. Prog. Phys. Geogr. Earth Environ. 2014, 38, 464-498. [CrossRef]

29. Tang, Q.; Gao, H.; Lu, H.; Lettenmaier, D.P. Remote sensing: Hydrology. Prog. Phys. Geogr. Earth Environ. 2009, 33, 490-509. [CrossRef]

30. Nitze, I.; Grosse, G.; Jones, B.M.; Arp, C.D.; Ulrich, M.; Fedorov, A.; Veremeeva, A. Landsat-Based Trend Analysis of Lake Dynamics across Northern Permafrost Regions. Remote Sens. 2017, 9, 640. [CrossRef]

31. Griffin, C.G.; McClelland, J.W.; Frey, K.E.; Fiske, G.; Holmes, R.M. Quantifying CDOM and DOC in major Arctic rivers during ice-free conditions using Landsat TM and ETM+ data. Remote Sens. Environ. 2018, 209, 395-409. [CrossRef]

32. Zhu, W.N.; Tian, Y.Q.; Yu, Q.; Becker, B.L. Using Hyperion imagery to monitor the spatial and temporal distribution of colored dissolved organic matter in estuarine and coastal regions. Remote Sens. Environ. 2013, 134, 342-354. [CrossRef]

33. Troitskaya, Y.; Rybushkina, G.; Soustova, I.; Lebedev, S. Adaptive Retracking of Jason-1, 2 Satellite Altimetry Data for the Volga River Reservoirs. IEEE J. Sel. Top. Appl. Earth Obs. Remote Sens. 2014, 7, 1603-1608. [CrossRef]

34. Arvor, D.; Daher, F.R.G.; Briand, D.; Dufour, S.; Rollet, A.J.; Simoes, M.; Ferraz, R.P.D. Monitoring thirty years of small water reservoirs proliferation in the southern Brazilian Amazon with Landsat time series. ISPRS J. Photogramm. Remote Sens. 2018, 145, 225-237. [CrossRef]

35. Costa, M.P.F.; Niemann, O.; Novo, E.; Ahern, F. Biophysical properties and mapping of aquatic vegetation during the hydrological cycle of the Amazon floodplain using JERS-1 and Radarsat. Int. J. Remote Sens. 2002, 23, 1401-1426. [CrossRef]

36. Pereira, V.F.G.; Congalton, R.G.; Zarin, D.J. Spatial and temporal analysis of a tidal floodplain landscape-Arnapi, Brazil-Using geographic information systems and remote sensing. Photogramm. Eng. Remote Sens. 2002, 68, 463-472.

37. Furtado, L.F.D.; Silva, T.S.F.; Novo, E. Dual-season and full-polarimetric C band SAR assessment for vegetation mapping in the Amazon varzea wetlands. Remote Sens. Environ. 2016, 174, 212-222. [CrossRef]

38. Wang, F.; Wang, Z.M.; Yang, H.B.; Zhao, Y.; Li, Z.H.; Wu, J.P. Capability of Remotely Sensed Drought Indices for Representing the Spatio-Temporal Variations of the Meteorological Droughts in the Yellow River Basin. Remote Sens. 2018, 10, 1834. [CrossRef]

39. Ge, J.; Meng, B.P.; Liang, T.G.; Feng, Q.S.; Gao, J.L.; Yang, S.X.; Huang, X.D.; Xie, H.J. Modeling alpine grassland cover based on MODIS data and support vector machine regression in the headwater region of the Huanghe River, China. Remote Sens. Environ. 2018, 218, 162-173. [CrossRef] 
40. Du, J.Y.; Kimball, J.S.; Jones, L.A.; Watts, J.D. Implementation of satellite based fractional water cover indices in the pan-Arctic region using AMSR-E and MODIS. Remote Sens. Environ. 2016, 184, 469-481. [CrossRef]

41. Kuenzer, C.; Klein, I.; Ullmann, T.; Georgiou, E.F.; Baumhauer, R.; Dech, S. Remote Sensing of River Delta Inundation: Exploiting the Potential of Coarse Spatial Resolution, Temporally-Dense MODIS Time Series. Remote Sens. 2015, 7, 8516-8542. [CrossRef]

42. Thenkabail, P.S.; Schull, M.; Turral, H. Ganges and Indus river basin land use/land cover (LULC) and irrigated area mapping using continuous streams of MODIS data. Remote Sens. Environ. 2005, 95, 317-341. [CrossRef]

43. Matthews, E. Global vegetation and land use: New high-resolution data bases for climate studies. J. Clim. Appl. Meteorol. 1983, 22, 474-487. [CrossRef]

44. Loveland, T.R.; Reed, B.C.; Brown, J.F.; Ohlen, D.O.; Zhu, Z.; Yang, L.; Merchant, J.W. Development of a global land cover characteristics database and IGBP DISCover from $1 \mathrm{~km}$ AVHRR data. Int. J. Remote Sens. 2000, 21, 1303-1330. [CrossRef]

45. Wang, C.; Jia, M.M.; Chen, N.C.; Wang, W. Long-Term Surface Water Dynamics Analysis Based on Landsat Imagery and the Google Earth Engine Platform: A Case Study in the Middle Yangtze River Basin. Remote Sens. 2018, 10, 1635. [CrossRef]

46. Frolking, S.; Milliman, T.; Palace, M.; Wisser, D.; Lammers, R.; Fahnestock, M. Tropical forest backscatter anomaly evident in Sea Winds scatterometer morning overpass data during 2005 drought in Amazonia. Remote Sens. Environ. 2011, 115, 897-907. [CrossRef]

47. Yuan, T.; Lee, H.; Jung, H.C. Toward Estimating Wetland Water Level Changes Based on Hydrological Sensitivity Analysis of PALSAR Backscattering Coefficients over Different Vegetation Fields. Remote Sens. 2015, 7, 3153-3183. [CrossRef]

48. Bartholomé, E.; Belward, A.S. GLC2000: A new approach to global land cover mapping from Earth observation data. Int. J. Remote Sens. 2005, 26, 1959-1977. [CrossRef]

49. Friedl, M.A.; McIver, D.K.; Hodges, J.C.; Zhang, X.Y.; Muchoney, D.; Strahler, A.H.; Woodcock, C.E.; Gopal, S.; Schneider, A.; Cooper, A. Global land cover mapping from MODIS: Algorithms and early results. Remote Sens. Environ. 2002, 83, 287-302. [CrossRef]

50. Arino, O.; Gross, D.; Ranera, F.; Leroy, M.; Bicheron, P.; Brockman, C.; Defourny, P.; Vancutsem, C.; Achard, F.; Durieux, L.; et al. GlobCover: ESA service for global land cover from MERIS. In Proceedings of the 2007 IEEE International Geoscience and Remote Sensing Symposium, Barcelona, Spain, 23-28 July 2007; pp. 2412-2415. [CrossRef]

51. Jun, C.; Ban, Y.; Li, S. Open access to Earth land-cover map. Nature 2014, 514, 434. [CrossRef]

52. Pittman, K.; Hansen, M.C.; Becker-Reshef, I.; Potapov, P.V.; Justice, C.O. Estimating global cropland extent with multi-year MODIS data. Remote Sens. 2010, 2, 1844-1863. [CrossRef]

53. Döll, P.; Siebert, S. A digital global map of irrigated areas. ICID J. 2000, 49, 55-66.

54. Hansen, M.C.; Potapov, P.V.; Moore, R.; Hancher, M.; Turubanova, S.A.; Tyukavina, A.; Thau, D.; Stehman, S.V.; Goetz, S.J.; Loveland, T.R.; et al. High-Resolution Global Maps of 21st-Century Forest Cover Change. Science 2013, 342, 850. [CrossRef] [PubMed]

55. Justice, C.O.; Townshend, J.R.G.; Vermote, E.F.; Masuoka, E.; Wolfe, R.E.; Saleous, N.; Roy, D.P.; Morisette, J.T. An overview of MODIS Land data processing and product status. Remote Sens. Environ. 2002, 83, 3-15. [CrossRef]

56. Verger, A.; Baret, F.; Weiss, M. Near Real-Time Vegetation Monitoring at Global Scale. IEEE J. Sel. Top. Appl. Earth Obs. Remote Sens. 2014, 7, 3473-3481. [CrossRef]

57. Tansey, K.; Grégoire, J.M.; Defourny, P.; Leigh, R.; Pekel, J.F.; van Bogaert, E.; Bartholomé, E. A new, global, multi-annual (2000-2007) burnt area product at $1 \mathrm{~km}$ resolution. Geophys. Res. Lett. 2008, 35. [CrossRef]

58. Pesaresi, M.; Huadong, G.; Blaes, X.; Ehrlich, D.; Ferri, S.; Gueguen, L.; Halkia, M.; Kauffmann, M.; Kemper, T.; Lu, L. A global human settlement layer from optical HR/VHR RS data: Concept and first results. IEEE J. Sel. Top. Appl. Earth Obs. Remote Sens. 2013, 6, 2102-2131. [CrossRef]

59. Esch, T.; Marconcini, M.; Felbier, A.; Roth, A.; Heldens, W.; Huber, M.; Schwinger, M.; Taubenböck, H.; Müller, A.; Dech, S. Urban footprint processor-Fully automated processing chain generating settlement masks from global data of the TanDEM-X mission. IEEE Geosci. Remote Sens. Lett. 2013, 10, 1617-1621. [CrossRef] 
60. Marconcini, M.; Metz-Marconcini, A.; Üreyen, S.; Palacios-Lopez, D.; Hanke, W.; Bachofer, F.; Zeidler, J.; Esch, T.; Gorelick, N.; Kakarla, A. Outlining where humans live-The World Settlement Footprint 2015. arXiv 2019, arXiv:1910.12707.

61. Giachetta, E.; Willett, S.D. A global dataset of river network geometry. Sci. Data 2018, 5, 180127. [CrossRef]

62. Calmant, S.; da Silva, J.S.; Moreira, D.M.; Seyler, F.; Shum, C.K.; Crétaux, J.F.; Gabalda, G. Detection of Envisat RA2/ICE-1 retracked radar altimetry bias over the Amazon basin rivers using GPS. Adv. Space Res. 2013, 51, 1551-1564. [CrossRef]

63. Crétaux, J.F.; Jelinski, W.; Calmant, S.; Kouraev, A.; Vuglinski, V.; Bergé-Nguyen, M.; Gennero, M.C.; Nino, F.; Abarca Del Rio, R.; Cazenave, A.; et al. SOLS: A lake database to monitor in the Near Real Time water level and storage variations from remote sensing data. Adv. Space Res. 2011, 47, 1497-1507. [CrossRef]

64. Pekel, J.F.; Cottam, A.; Gorelick, N.; Belward, A.S. High-resolution mapping of global surface water and its long-term changes. Nature 2016, 540, 418. [CrossRef] [PubMed]

65. Klein, I.; Gessner, U.; Dietz, A.J.; Kuenzer, C. Global WaterPack-A 250m resolution dataset revealing the daily dynamics of global inland water bodies. Remote Sens. Environ. 2017, 198, 345-362. [CrossRef]

66. Dietz, A.J.; Kuenzer, C.; Dech, S. Global SnowPack: A new set of snow cover parameters for studying status and dynamics of the planetary snow cover extent. Remote Sens. Lett. 2015, 6, 844-853. [CrossRef]

67. Esch, T.; Üreyen, S.; Zeidler, J.; Metz-Marconcini, A.; Hirner, A.; Asamer, H.; Tum, M.; Böttcher, M.; Kuchar, S.; Svaton, V.; et al. Exploiting big earth data from space-First experiences with the timescan processing chain. Big Earth Data 2018, 2, 36-55. [CrossRef]

68. Lehner, B.; Liermann, C.R.; Revenga, C.; Vörösmarty, C.; Fekete, B.; Crouzet, P.; Döll, P.; Endejan, M.; Frenken, K.; Magome, J.; et al. High-resolution mapping of the world's reservoirs and dams for sustainable river-flow management. Front. Ecol. Environ. 2011, 9, 494-502. [CrossRef]

69. OpenStreetMap Contributors. 2019. Available online: https://www.openstreetmap.org (accessed on 12 April 2019).

70. Saatchi, S.S.; Nelson, B.; Podest, E.; Holt, J. Mapping land cover types in the Amazon Basin using $1 \mathrm{~km}$ JERS-1 mosaic. Int. J. Remote Sens. 2000, 21, 1201-1234. [CrossRef]

71. Matsuoka, M.; Hayasaka, T.; Fukushima, Y.; Honda, Y. Land cover in East Asia classified using Terra MODIS and DMSP OLS products. Int. J. Remote Sens. 2007, 28, 221-248. [CrossRef]

72. Wang, S.Y.; Ding, C.B.; Liu, J.S. Landscape evolution in the Yellow River Basin using satellite remote sensing and GIS during the past decade. Int. J. Remote Sens. 2009, 30, 5573-5591. [CrossRef]

73. Leinenkugel, P.; Kuenzer, C.; Oppelt, N.; Dech, S. Characterisation of land surface phenology and land cover based on moderate resolution satellite data in cloud prone areas-A novel product for the Mekong Basin. Remote Sens. Environ. 2013, 136, 180-198. [CrossRef]

74. Schneider, J.; Grosse, G.; Wagner, D. Land cover classification of tundra environments in the Arctic Lena Delta based on Landsat 7 ETM+ data and its application for upscaling of methane emissions. Remote Sens. Environ. 2009, 113, 380-391. [CrossRef]

75. Ulrich, M.; Grosse, G.; Chabrillat, S.; Schirrmeister, L. Spectral characterization of periglacial surfaces and geomorphological units in the Arctic Lena Delta using field spectrometry and remote sensing. Remote Sens. Environ. 2009, 113, 1220-1235. [CrossRef]

76. Ullmann, T.; Schmitt, A.; Roth, A.; Duffe, J.; Dech, S.; Hubberten, H.W.; Baumhauer, R. Land Cover Characterization and Classification of Arctic Tundra Environments by Means of Polarized Synthetic Aperture $\mathrm{X}$ - and C-Band Radar (PolSAR) and Landsat 8 Multispectral Imagery—Richards Island, Canada. Remote Sens. 2014, 6, 8565-8593. [CrossRef]

77. Walker, W.S.; Stickler, C.M.; Kellndorfer, J.M.; Kirsch, K.M.; Nepstad, D.C. Large-Area Classification and Mapping of Forest and Land Cover in the Brazilian Amazon: A Comparative Analysis of ALOS/PALSAR and Landsat Data Sources. IEEE J. Sel. Top. Appl. Earth Obs. Remote Sens. 2010, 3, 594-604. [CrossRef]

78. Liu, J.T.; Feng, Q.L.; Gong, J.H.; Zhou, J.P.; Li, Y. Land-cover classification of the Yellow River Delta wetland based on multiple end-member spectral mixture analysis and a Random Forest classifier. Int. J. Remote Sens. 2016, 37, 1845-1867. [CrossRef]

79. Guan, X.D.; Liu, G.H.; Huang, C.; Liu, Q.S.; Wu, C.S.; Jin, Y.; Li, Y.F. An Object-Based Linear Weight Assignment Fusion Scheme to Improve Classification Accuracy Using Landsat and MODIS Data at the Decision Level. IEEE Trans. Geosci. Remote Sens. 2017, 55, 6989-7002. [CrossRef] 
80. Buono, A.; Nunziata, F.; Migliaccio, M.; Yang, X.; Li, X. Classification of the Yellow River delta area using fully polarimetric SAR measurements. Int. J. Remote Sens. 2017, 38, 6714-6734. [CrossRef]

81. Zhang, J.X.; Liu, Z.J.; Sun, X.X. Changing landscape in the Three Gorges Reservoir Area of Yangtze River from 1977 to 2005: Land use/land cover, vegetation cover changes estimated using multi-source satellite data. Int. J. Appl. Earth Obs. Geoinf. 2009, 11, 403-412. [CrossRef]

82. Chen, Z.H.; Wang, J.F. Land use and land cover change detection using satellite remote sensing techniques in the mountainous Three Gorges Area, China. Int. J. Remote Sens. 2010, 31, 1519-1542. [CrossRef]

83. Zhao, Q.H.; Liu, S.L.; Deng, L.; Dong, S.K.; Wang, C.; Yang, Z.F.; Yang, J.J. Landscape change and hydrologic alteration associated with dam construction. Int. J. Appl. Earth Obs. Geoinf. 2012, 16, 17-26. [CrossRef]

84. Wang, L.J.; Wu, L.; Hou, X.Y.; Zheng, B.H.; Li, H.; Norra, S. Role of reservoir construction in regional land use change in Pengxi River basin upstream of the Three Gorges Reservoir in China. Environ. Earth Sci. 2016, 75, 15. [CrossRef]

85. Feng, Y.Y.; Lu, D.S.; Moran, E.F.; Dutra, L.V.; Calvi, M.F.; de Oliveira, M.A.F. Examining Spatial Distribution and Dynamic Change of Urban Land Covers in the Brazilian Amazon Using Multitemporal Multisensor High Spatial Resolution Satellite Imagery. Remote Sens. 2017, 9, 381. [CrossRef]

86. Dewidar, K.M. Detection of land use land cover changes for the northern part of the Nile delta (Burullus region), Egypt. Int. J. Remote Sens. 2004, 25, 4079-4089. [CrossRef]

87. Abdulaziz, A.M.; Hurtado, J.M.; Al-Douri, R. Application of multitemporal Landsat data to monitor land cover changes in the Eastern Nile Delta region, Egypt. Int. J. Remote Sens. 2009, 30, 2977-2996. [CrossRef]

88. Bakr, N.; Weindorf, D.C.; Bahnassy, M.H.; Marei, S.M.; El-Badawi, M.M. Monitoring land cover changes in a newly reclaimed area of Egypt using multi-temporal Landsat data. Appl. Geogr. 2010, 30, 592-605. [CrossRef]

89. Abd El-Kawy, O.R.; Rød, J.K.; Ismail, H.A.; Suliman, A.S. Land use and land cover change detection in the western Nile delta of Egypt using remote sensing data. Appl. Geogr. 2011, 31, 483-494. [CrossRef]

90. Faid, A.M.; Abdulaziz, A.M. Monitoring land-use change-associated land development using multitemporal Landsat data and geoinformatics in Kom Ombo area, South Egypt. Int. J. Remote Sens. 2012, 33, 7024-7046. [CrossRef]

91. Ruelland, D.; Dezetter, A.; Puech, C.; Ardoin-Bardin, S. Long-term monitoring of land cover changes based on Landsat imagery to improve hydrological modelling in West Africa. Int. J. Remote Sens. 2008, 29, 3533-3551. [CrossRef]

92. Ruelland, D.; Tribotte, A.; Puech, C.; Dieulin, C. Comparison of methods for LUCC monitoring over 50 years from aerial photographs and satellite images in a Sahelian catchment. Int. J. Remote Sens. 2011, 32, 1747-1777. [CrossRef]

93. Kuenzer, C.; van Beijma, S.; Gessner, U.; Dech, S. Land surface dynamics and environmental challenges of the Niger Delta, Africa: Remote sensing-based analyses spanning three decades (1986-2013). Appl. Geogr. 2014, 53, 354-368. [CrossRef]

94. Verhegghen, A.; Eva, H.; Ceccherini, G.; Achard, F.; Gond, V.; Gourlet-Fleury, S.; Cerutti, P.O. The Potential of Sentinel Satellites for Burnt Area Mapping and Monitoring in the Congo Basin Forests. Remote Sens. 2016, 8, 986. [CrossRef]

95. Gaughan, A.E.; Binford, M.W.; Southworth, J. Tourism, forest conversion, and land transformations in the Angkor basin, Cambodia. Appl. Geogr. 2009, 29, 212-223. [CrossRef]

96. Haas, J.; Ban, Y.F. Urban growth and environmental impacts in Jing-Jin-Ji, the Yangtze, River Delta and the Pearl River Delta. Int. J. Appl. Earth Obs. Geoinf. 2014, 30, 42-55. [CrossRef]

97. Hu, G.Y.; Jin, H.J.; Dong, Z.B.; Lu, J.F.; Yan, C.Z. Driving forces of aeolian desertification in the source region of the Yellow River: 1975-2005. Environ. Earth Sci. 2013, 70, 3245-3254. [CrossRef]

98. Ren, X.B.; Dong, Z.B.; Hu, G.Y.; Zhang, D.H.; Li, Q. A GIS-Based Assessment of Vulnerability to Aeolian Desertification in the Source Areas of the Yangtze and Yellow Rivers. Remote Sens. 2016, 8, 626. [CrossRef]

99. Wohlfart, C.; Mack, B.; Liu, G.; Kuenzer, C. Multi-faceted land cover and land use change analyses in the Yellow River Basin based on dense Landsat time series: Exemplary analysis in mining, agriculture, forest, and urban areas. Appl. Geogr. 2017, 85, 73-88. [CrossRef]

100. De Moura, Y.M.; Hilker, T.; Lyapustin, A.I.; Galva, L.S.; dos Santos, J.R.; Anderson, L.O.; de Sousa, C.H.R.; Arai, E. Seasonality and drought effects of Amazonian forests observed from multi-angle satellite data. Remote Sens. Environ. 2015, 171, 278-290. [CrossRef] 
101. Hilker, T.; Lyapustin, A.I.; Hall, F.G.; Myneni, R.; Knyazikhin, Y.; Wang, Y.J.; Tucker, C.J.; Sellers, P.J. On the measurability of change in Amazon vegetation from MODIS. Remote Sens. Environ. 2015, 166, 233-242. [CrossRef]

102. Duveiller, G.; Defourny, P.; Desclee, B.; Mayaux, P. Deforestation in Central Africa: Estimates at regional, national and landscape levels by advanced processing of systematically-distributed Landsat extracts. Remote Sens. Environ. 2008, 112, 1969-1981. [CrossRef]

103. Yan, D.; Zhang, X.Y.; Yu, Y.Y.; Guo, W. A Comparison of Tropical Rainforest Phenology Retrieved From Geostationary (SEVIRI) and Polar-Orbiting (MODIS) Sensors Across the Congo Basin. IEEE Trans. Geosci. Remote Sens. 2016, 54, 4867-4881. [CrossRef]

104. Yan, D.; Zhang, X.Y.; Yu, Y.Y.; Guo, W. Characterizing Land Cover Impacts on the Responses of Land Surface Phenology to the Rainy Season in the Congo Basin. Remote Sens. 2017, 9, 461. [CrossRef]

105. Podest, E.; Saatchi, S. Application of multiscale texture in classifying JERS-1 radar data over tropical vegetation. Int. J. Remote Sens. 2002, 23, 1487-1506. [CrossRef]

106. Lu, D.S.; Moran, E.; Batistella, M. Linear mixture model applied to Amazonian vegetation classification. Remote Sens. Environ. 2003, 87, 456-469. [CrossRef]

107. McCleary, A.L.; Crews-Meyer, K.A.; Young, K.R. Refining forest classifications in the western Amazon using an intra-annual multitemporal approach. Int. J. Remote Sens. 2008, 29, 991-1006. [CrossRef]

108. Silva, T.S.F.; Costa, M.P.F.; Melack, J.M. Spatial and temporal variability of macrophyte cover and productivity in the eastern Amazon floodplain: A remote sensing approach. Remote Sens. Environ. 2010, 114, 1998-2010. [CrossRef]

109. Sartori, L.R.; Imai, N.N.; Mura, J.C.; Novo, E.; Silva, T.S.F. Mapping Macrophyte Species in the Amazon Floodplain Wetlands Using Fully Polarimetric ALOS/PALSAR Data. IEEE Trans. Geosci. Remote Sens. 2011, 49, 4717-4728. [CrossRef]

110. Tong, P.H.S.; Auda, Y.; Populus, J.; Aizpuru, M.; Al Habshi, A.; Blasco, F. Assessment from space of mangroves evolution in the Mekong Delta, in relation to extensive shrimp farming. Int. J. Remote Sens. 2004, 25, 4795-4812. [CrossRef]

111. Vo, Q.T.; Oppelt, N.; Leinenkugel, P.; Kuenzer, C. Remote Sensing in Mapping Mangrove Ecosystems-An Object-Based Approach. Remote Sens. 2013, 5, 183-201. [CrossRef]

112. Lagomasino, D.; Fatoyinbo, T.; Lee, S.; Feliciano, E.; Trettin, C.; Simard, M. A Comparison of Mangrove Canopy Height Using Multiple Independent Measurements from Land, Air, and Space. Remote Sens. 2016, 8, 327. [CrossRef]

113. Reno, V.F.; Novo, E.; Suemitsu, C.; Renno, C.D.; Silva, T.S.F. Assessment of deforestation in the Lower Amazon floodplain using historical Landsat MSS/TM imagery. Remote Sens. Environ. 2011, 115, 3446-3456. [CrossRef]

114. Souza, C.M.; Siqueira, J.V.; Sales, M.H.; Fonseca, A.V.; Ribeiro, J.G.; Numata, I.; Cochrane, M.A.; Barber, C.P.; Roberts, D.A.; Barlow, J. Ten-Year Landsat Classification of Deforestation and Forest Degradation in the Brazilian Amazon. Remote Sens. 2013, 5, 5493-5513. [CrossRef]

115. Chen, G.; Powers, R.P.; de Carvalho, L.M.T.; Mora, B. Spatiotemporal patterns of tropical deforestation and forest degradation in response to the operation of the Tucuruí hydroelectricdam in the Amazon basin. Appl. Geogr. 2015, 63, 1-8. [CrossRef]

116. Yoshikawa, S.; Sanga-Ngoie, K. Deforestation dynamics in Mato Grosso in the southern Brazilian Amazon using GIS and NOAA/AVHRR data. Int. J. Remote Sens. 2011, 32, 523-544. [CrossRef]

117. Leinenkugel, P.; Wolters, M.L.; Oppelt, N.; Kuenzer, C. Tree cover and forest cover dynamics in the Mekong Basin from 2001 to 2011. Remote Sens. Environ. 2015, 158, 376-392. [CrossRef]

118. Huang, S.L.; Jin, S.M.; Dahal, D.; Chen, X.X.; Young, C.; Liu, H.P.; Liu, S.G. Reconstructing satellite images to quantify spatially explicit land surface change caused by fires and succession: A demonstration in the Yukon River Basin of interior Alaska. ISPRS J. Photogramm. Remote Sens. 2013, 79, 94-105. [CrossRef]

119. Tan, Z.X.; Liu, S.G.; Wylie, B.K.; Jenkerson, C.B.; Oeding, J.; Rover, J.; Young, C. MODIS-informed greenness responses to daytime land surface temperature fluctuations and wildfire disturbances in the Alaskan Yukon River Basin. Int. J. Remote Sens. 2013, 34, 2187-2199. [CrossRef]

120. Liang, S.H.; Ge, S.M.; Wan, L.; Xu, D.W. Characteristics and causes of vegetation variation in the source regions of the Yellow River, China. Int. J. Remote Sens. 2012, 33, 1529-1542. [CrossRef] 
121. Liu, X.F.; Zhu, X.F.; Zhu, W.Q.; Pan, Y.Z.; Zhang, C.; Zhang, D.H. Changes in Spring Phenology in the Three-Rivers Headwater Region from 1999 to 2013. Remote Sens. 2014, 6, 9130-9144. [CrossRef]

122. Campo-Bescos, M.A.; Munoz-Carpena, R.; Southworth, J.; Zhu, L.K.; Waylen, P.R.; Bunting, E. Combined Spatial and Temporal Effects of Environmental Controls on Long-Term Monthly NDVI in the Southern Africa Savanna. Remote Sens. 2013, 5, 6513-6538. [CrossRef]

123. Shapiro, A.C.; Trettin, C.C.; Kuchly, H.; Alavinapanah, S.; Bandeira, S. The Mangroves of the Zambezi Delta: Increase in Extent Observed via Satellite from 1994 to 2013. Remote Sens. 2015, 7, 16504-16518. [CrossRef]

124. Bunting, E.L.; Southworth, J.; Herrero, H.; Ryan, S.J.; Waylen, P. Understanding Long-Term Savanna Vegetation Persistence across Three Drainage Basins in Southern Africa. Remote Sens. 2018, 10, 1013. [CrossRef]

125. Son, N.T.; Chen, C.F.; Chen, C.R.; Duc, H.N.; Chang, L.Y. A Phenology-Based Classification of Time-Series MODIS Data for Rice Crop Monitoring in Mekong Delta, Vietnam. Remote Sens. 2014, 6, 135-156. [CrossRef]

126. Kontgis, C.; Schneider, A.; Ozdogan, M. Mapping rice paddy extent and intensification in the Vietnamese Mekong River Delta with dense time stacks of Landsat data. Remote Sens. Environ. 2015, 169, 255-269. [CrossRef]

127. Nguyen, D.B.; Clauss, K.; Cao, S.M.; Naeimi, V.; Kuenzer, C.; Wagner, W. Mapping Rice Seasonality in the Mekong Delta with Multi-Year Envisat ASAR WSM Data. Remote Sens. 2015, 7, 15868-15893. [CrossRef]

128. Clauss, K.; Ottinger, M.; Kuenzer, C. Mapping rice areas with Sentinel-1 time series and superpixel segmentation. Int. J. Remote Sens. 2018, 39, 1399-1420. [CrossRef]

129. Clauss, K.; Ottinger, M.; Leinenkugel, P.; Kuenzer, C. Estimating rice production in the Mekong Delta, Vietnam, utilizing time series of Sentinel-1 SAR data. Int. J. Appl. Earth Obs. Geoinf. 2018, 73, 574-585. [CrossRef]

130. Cardille, J.A.; Foley, J.A. Agricultural land-use change in Brazilian Amazonia between 1980 and 1995 : Evidence from integrated satellite and census data. Remote Sens. Environ. 2003, 87, 551-562. [CrossRef]

131. Xu, Y.D.; Yu, L.; Zhao, Y.Y.; Feng, D.L.; Cheng, Y.Q.; Cai, X.L.; Gong, P. Monitoring cropland changes along the Nile River in Egypt over past three decades (1984-2015) using remote sensing. Int. J. Remote Sens. 2017, 38, 4459-4480. [CrossRef]

132. Shi, J.J.; Huang, J.F. Monitoring Spatio-Temporal Distribution of Rice Planting Area in the Yangtze River Delta Region Using MODIS Images. Remote Sens. 2015, 7, 8883-8905. [CrossRef]

133. Du, H.Y.; Wang, D.D.; Wang, Y.Y.; Zhao, X.L.; Qin, F.; Jiang, H.; Cai, Y.L. Influences of land cover types, meteorological conditions, anthropogenic heat and urban area on surface urban heat island in the Yangtze River Delta Urban Agglomeration. Sci. Total Environ. 2016, 571, 461-470. [CrossRef]

134. Zhou, D.C.; Bonafoni, S.; Zhang, L.X.; Wang, R.H. Remote sensing of the urban heat island effect in a highly populated urban agglomeration area in East China. Sci. Total Environ. 2018, 628-629, 415-429. [CrossRef]

135. Yao, R.; Wang, L.C.; Gui, X.; Zheng, Y.K.; Zhang, H.M.; Huang, X. Urbanization Effects on Vegetation and Surface Urban Heat Islands in China's Yangtze River Basin. Remote Sens. 2017, 9, 540. [CrossRef]

136. Xiao, P.F.; Wang, X.H.; Feng, X.Z.; Zhang, X.L.; Yang, Y.K. Detecting China's Urban Expansion Over the Past Three Decades Using Nighttime Light Data. IEEE J. Sel. Top. Appl. Earth Obs. Remote Sens. 2014, 7, 4095-4106. [CrossRef]

137. Wang, Z.; Yang, S.; Wang, S.G.; Shen, Y. Monitoring evolving urban cluster systems using DMSP/OLS nighttime light data: A case study of the Yangtze River Delta region, China. J. Appl. Remote Sens. 2017, 11, 17. [CrossRef]

138. Zou, Y.H.; Peng, H.Q.; Liu, G.; Yang, K.D.; Xie, Y.H.; Weng, Q.H. Monitoring Urban Clusters Expansion in the Middle Reaches of the Yangtze River, China, Using Time-Series Nighttime Light Images. Remote Sens. 2017, 9, 1007. [CrossRef]

139. Liu, Y.; Zhang, X.; Kong, X.; Wang, R.; Chen, L. Identifying the relationship between urban land expansion and human activities in the Yangtze River Economic Belt, China. Appl. Geogr. 2018, 94, 163-177. [CrossRef]

140. Shao, Z.F.; Liu, C. The Integrated Use of DMSP-OLS Nighttime Light and MODIS Data for Monitoring Large-Scale Impervious Surface Dynamics: A Case Study in the Yangtze River Delta. Remote Sens. 2014, 6, 9359-9378. [CrossRef]

141. Zhuo, L.; Shi, Q.L.; Tao, H.Y.; Zheng, J.; Li, Q.P. An improved temporal mixture analysis unmixing method for estimating impervious surface area based on MODIS and DMSP-OLS data. ISPRS J. Photogramm. Remote Sens. 2018, 142, 64-77. [CrossRef] 
142. Liu, D.D.; Chen, N.C. Satellite Monitoring of Urban Land Change in the Middle Yangtze River Basin Urban Agglomeration, China between 2000 and 2016. Remote Sens. 2017, 9, 1086. [CrossRef]

143. Leinenkugel, P.; Esch, T.; Kuenzer, C. Settlement detection and impervious surface estimation in the Mekong Delta using optical and SAR remote sensing data. Remote Sens. Environ. 2011, 115, 3007-3019. [CrossRef]

144. Amer, R.; Kolker, A.S.; Muscietta, A. Propensity for erosion and deposition in a deltaic wetland complex: Implications for river management and coastal restoration. Remote Sens. Environ. 2017, 199, 39-50. [CrossRef]

145. El-Asmar, H.M.; Hereher, M.E. Change detection of the coastal zone east of the Nile Delta using remote sensing. Environ. Earth Sci. 2011, 62, 769-777. [CrossRef]

146. Hereher, M.E. Mapping coastal erosion at the Nile Delta western promontory using Landsat imagery. Environ. Earth Sci. 2011, 64, 1117-1125. [CrossRef]

147. Li, X.; Zhou, Y.X.; Zhang, L.P.; Kuang, R.Y. Shoreline change of Chongming Dongtan and response to river sediment load: A remote sensing assessment. J. Hydrol. 2014, 511, 432-442. [CrossRef]

148. Zhang, L.; Wu, B.F.; Yin, K.; Li, X.S.; Kia, K.; Zhu, L. Impacts of human activities on the evolution of estuarine wetland in the Yangtze Delta from 2000 to 2010. Environ. Earth Sci. 2015, 73, 435-447. [CrossRef]

149. Qiao, G.; Mi, H.; Wang, W.A.; Tong, X.H.; Li, Z.B.; Li, T.; Liu, S.J.; Hong, Y. 55-year (1960-2015) spatiotemporal shoreline change analysis using historical DISP and Landsat time series data in Shanghai. Int. J. Appl. Earth Obs. Geoinf. 2018, 68, 238-251. [CrossRef]

150. Liu, Y.X.; Huang, H.J.; Qiu, Z.F.; Fan, J.Y. Detecting coastline change from satellite images based on beach slope estimation in a tidal flat. Int. J. Appl. Earth Obs. Geoinf. 2013, 23, 165-176. [CrossRef]

151. Kuenzer, C.; Ottinger, M.; Liu, G.; Sun, B.; Baumhauer, R.; Dech, S. Earth observation-based coastal zone monitoring of the Yellow River Delta: Dynamics in China's second largest oil producing region over four decades. Appl. Geogr. 2014, 55, 92-107. [CrossRef]

152. Kong, D.X.; Miao, C.Y.; Borthwick, A.G.L.; Duan, Q.Y.; Liu, H.; Sun, Q.H.; Ye, A.Z.; Di, Z.H.; Gong, W. Evolution of the Yellow River Delta and its relationship with runoff and sediment load from 1983 to 2011. J. Hydrol. 2015, 520, 157-167. [CrossRef]

153. Arnesen, A.S.; Silva, T.S.F.; Hess, L.L.; Novo, E.; Rudorff, C.M.; Chapman, B.D.; McDonald, K.C. Monitoring flood extent in the lower Amazon River floodplain using ALOS/PALSAR ScanSAR images. Remote Sens. Environ. 2013, 130, 51-61. [CrossRef]

154. Hamilton, S.K.; Sippel, S.J.; Melack, J.M. Seasonal inundation patterns in two large savanna floodplains of South America: The Llanos de Moxos (Bolivia) and the Llanos del Orinoco (Venezuela and Colombia). Hydrol. Process. 2004, 18, 2103-2116. [CrossRef]

155. Chapman, B.; McDonald, K.; Shimada, M.; Rosenqvist, A.; Schroeder, R.; Hess, L. Mapping Regional Inundation with Spaceborne L-Band SAR. Remote Sens. 2015, 7, 5440-5470. [CrossRef]

156. Rosenqvist, A.; Birkett, C.M. Evaluation of JERS-1 SAR mosaics for hydrological applications in the Congo river basin. Int. J. Remote Sens. 2002, 23, 1283-1302. [CrossRef]

157. Khan, S.I.; Hong, Y.; Gourley, J.J.; Khattak, M.U.; De Groeve, T. Multi-Sensor Imaging and Space-Ground Cross-Validation for 2010 Flood along Indus River, Pakistan. Remote Sens. 2014, 6, 2393-2407. [CrossRef]

158. Kwak, Y.; Park, J.; Fukami, K. Near Real-Time Flood Volume Estimation From MODIS Time-Series Imagery in the Indus River Basin. IEEE J. Sel. Top. Appl. Earth Obs. Remote Sens. 2014, 7, 578-586. [CrossRef]

159. Donchyts, G.; Schellekens, J.; Winsemius, H.; Eisemann, E.; van de Giesen, N. A 30 m Resolution Surface Water Mask Including Estimation of Positional and Thematic Differences Using Landsat 8, SRTM and OpenStreetMap: A Case Study in the Murray-Darling Basin, Australia. Remote Sens. 2016, 8, 386. [CrossRef]

160. Heimhuber, V.; Tulbure, M.G.; Broich, M. Modeling 25 years of spatio-temporal surface water and inundation dynamics on large river basin scale using time series of Earth observation data. Hydrol. Earth Syst. Sci. 2016, 20, 2227-2250. [CrossRef]

161. Tulbure, M.G.; Broich, M.; Stehman, S.V.; Kommareddy, A. Surface water extent dynamics from three decades of seasonally continuous Landsat time series at subcontinental scale in a semi-arid region. Remote Sens. Environ. 2016, 178, 142-157. [CrossRef]

162. Heimhuber, V.; Tulbure, M.G.; Broich, M. Modeling multidecadal surface water inundation dynamics and key drivers on large river basin scale using multiple time series of Earth-observation and river flow data. Water Resour. Res. 2017, 53, 1251-1269. [CrossRef]

163. Rao, P.Z.; Jiang, W.G.; Hou, Y.K.; Chen, Z.; Jia, K. Dynamic Change Analysis of Surface Water in the Yangtze River Basin Based on MODIS Products. Remote Sens. 2018, 10, 1025. [CrossRef] 
164. Guerschman, J.P.; Warren, G.; Byrne, G.; Lymburner, L.; Mueller, N.; Van-Dijk, A. MODIS-Based Standing Water Detection for Flood and Large Reservoir Mapping: Algorithm Development and Applications for the Australian Continent; CSIRO: Canberra, Australia, 2011.

165. Wilusz, D.C.; Zaitchik, B.F.; Anderson, M.C.; Hain, C.R.; Yilmaz, M.T.; Mladenova, I.E. Monthly flooded area classification using low resolution SAR imagery in the Sudd wetland from 2007 to 2011. Remote Sens. Environ. 2017, 194, 205-218. [CrossRef]

166. Rosenqvist, A.; Forsberg, B.R.; Pimentel, T.; Rauste, Y.A.; Richey, J.E. The use of spaceborne radar data to model inundation patterns and trace gas emissions in the central Amazon floodplain. Int. J. Remote Sens. 2002, 23, 1303-1328. [CrossRef]

167. Hess, L.L.; Melack, J.M.; Novo, E.; Barbosa, C.C.F.; Gastil, M. Dual-season mapping of wetland inundation and vegetation for the central Amazon basin. Remote Sens. Environ. 2003, 87, 404-428. [CrossRef]

168. Sakamoto, T.; Van Nguyen, N.; Kotera, A.; Ohno, H.; Ishitsuka, N.; Yokozawa, M. Detecting temporal changes in the extent of annual flooding within the Cambodia and the Vietnamese Mekong Delta from MODIS time-series imagery. Remote Sens. Environ. 2007, 109, 295-313. [CrossRef]

169. Gstaiger, V.; Huth, J.; Gebhardt, S.; Wehrmann, T.; Kuenzer, C. Multi-sensoral and automated derivation of inundated areas using TerraSAR-X and ENVISAT ASAR data. Int. J. Remote Sens. 2012, 33, 7291-7304. [CrossRef]

170. Kuenzer, C.; Guo, H.D.; Huth, J.; Leinenkugel, P.; Li, X.W.; Dech, S. Flood Mapping and Flood Dynamics of the Mekong Delta: ENVISAT-ASAR-WSM Based Time Series Analyses. Remote Sens. 2013, 5, 687-715. [CrossRef]

171. Du, Z.Q.; Bin, L.H.; Ling, F.; Li, W.B.; Tian, W.D.; Wang, H.L.; Gui, Y.M.; Sun, B.Y.; Zhang, X.M. Estimating surface water area changes using time-series Landsat data in the Qingjiang River Basin, China. J. Appl. Remote Sens. 2012, 6, 16. [CrossRef]

172. Li, W.B.; Du, Z.Q.; Ling, F.; Zhou, D.B.; Wang, H.L.; Gui, Y.M.; Sun, B.Y.; Zhang, X.M. A Comparison of Land Surface Water Mapping Using the Normalized Difference Water Index from TM, ETM plus and ALI. Remote Sens. 2013, 5, 5530-5549. [CrossRef]

173. Bourrel, L.; Phillips, L.; Moreau, S. The dynamics of floods in the Bolivian Amazon Basin. Hydrol. Process. 2009, 23, 3161-3167. [CrossRef]

174. Cooley, S.W.; Smith, L.C.; Stepan, L.; Mascaro, J. Tracking Dynamic Northern Surface Water Changes with High-Frequency Planet CubeSat Imagery. Remote Sens. 2017, 9, 1306. [CrossRef]

175. Montanher, O.C.; Novo, E.; Barbosa, C.C.F.; Renno, C.D.; Silva, T.S.F. Empirical models for estimating the suspended sediment concentration in Amazonian white water rivers using Landsat 5/TM. Int. J. Appl. Earth Obs. Geoinf. 2014, 29, 67-77. [CrossRef]

176. Massicotte, P.; Gratton, D.; Frenette, J.J.; Assani, A.A. Spatial and temporal evolution of the St. Lawrence River spectral profile: A 25-year case study using Landsat 5 and 7 imagery. Remote Sens. Environ. 2013, 136, 433-441. [CrossRef]

177. Heege, T.; Kiselev, V.; Wettle, M.; Hung, N.N. Operational multi-sensor monitoring of turbidity for the entire Mekong Delta. Int. J. Remote Sens. 2014, 35, 2910-2926. [CrossRef]

178. Ren, J.L.; Zheng, Z.B.; Li, Y.M.; Lv, G.N.; Wang, Q.; Lyu, H.; Huang, C.C.; Liu, G.; Du, C.G.; Mu, M.; et al. Remote observation of water clarity patterns in Three Gorges Reservoir and Dongting Lake of China and their probable linkage to the Three Gorges Dam based on Landsat 8 imagery. Sci. Total Environ. 2018, 625, 1554-1566. [CrossRef] [PubMed]

179. Kuhn, C.; Valerio, A.D.; Ward, N.; Loken, L.; Sawakuchi, H.O.; Karnpel, M.; Richey, J.; Stadler, P.; Crawford, J.; Striegl, R.; et al. Performance of Landsat-8 and Sentinel-2 surface reflectance products for river remote sensing retrievals of chlorophyll-a and turbidity. Remote Sens. Environ. 2019, 224, 104-118. [CrossRef]

180. Peterson, K.T.; Sagan, V.; Sidike, P.; Cox, A.L.; Martinez, M. Suspended Sediment Concentration Estimation from Landsat Imagery along the Lower Missouri and Middle Mississippi Rivers Using an Extreme Learning Machine. Remote Sens. 2018, 10, 1503. [CrossRef]

181. Markert, K.N.; Schmidt, C.M.; Griffin, R.E.; Flores, A.I.; Poortinga, A.; Saah, D.S.; Muench, R.E.; Clinton, N.E.; Chishtie, F.; Kityuttachai, K.; et al. Historical and Operational Monitoring of Surface Sediments in the Lower Mekong Basin Using Landsat and Google Earth Engine Cloud Computing. Remote Sens. 2018, 10, 909. [CrossRef] 
182. Umar, M.; Rhoads, B.L.; Greenberg, J.A. Use of multispectral satellite remote sensing to assess mixing of suspended sediment downstream of large river confluences. J. Hydrol. 2018, 556, 325-338. [CrossRef]

183. Fassoni-Andrade, A.C.; de Paiva, R.C.D. Mapping spatial-temporal sediment dynamics of river-floodplains in the Amazon. Remote Sens. Environ. 2019, 221, 94-107. [CrossRef]

184. Park, E.; Latrubesse, E.M. Surface water types and sediment distribution patterns at the confluence of mega rivers: The Solimoes-Amazon and Negro Rivers junction. Water Resour. Res. 2015, 51, 6197-6213. [CrossRef]

185. Lobo, F.D.; Costa, M.; Novo, E.; Telmer, K. Distribution of Artisanal and Small-Scale Gold Mining in the Tapajos River Basin (Brazilian Amazon) over the Past 40 Years and Relationship with Water Siltation. Remote Sens. 2016, 8, 579. [CrossRef]

186. Carstens, D.; Amer, R. Spatio-temporal analysis of urban changes and surface water quality. J. Hydrol. 2019, 569, 720-734. [CrossRef]

187. Schwatke, C.; Dettmering, D.; Bosch, W.; Seitz, F. DAHITI-An innovative approach for estimating water level time series over inland waters using multi-mission satellite altimetry. Hydrol. Earth Syst. Sci. 2015, 19, 4345-4364. [CrossRef]

188. Birkett, C.M.; Mertes, L.A.K.; Dunne, T.; Costa, M.H.; Jasinski, M.J. Surface water dynamics in the Amazon Basin: Application of satellite radar altimetry. J. Geophys. Res. Atmos. 2002, 107, LBA 26-1-LBA 26-21. [CrossRef]

189. Berry, P.A.M.; Garlick, J.D.; Freeman, J.A.; Mathers, E.L. Global inland water monitoring from multi-mission altimetry. Geophys. Res. Lett. 2005, 32. [CrossRef]

190. Frappart, F.; Calmant, S.; Cauhope, M.; Seyler, F.; Cazenave, A. Preliminary results of ENVISAT RA-2-derived water levels validation over the Amazon basin. Remote Sens. Environ. 2006, 100, 252-264. [CrossRef]

191. Da Silva, J.S.; Calmant, S.; Seyler, F.; Rotunno, O.C.; Cochonneau, G.; Mansur, W.J. Water levels in the Amazon basin derived from the ERS 2 and ENVISAT radar altimetry missions. Remote Sens. Environ. 2010, 114, 2160-2181. [CrossRef]

192. Da Silva, J.S.; Seyler, F.; Calmant, S.; Rotunno, O.C.; Roux, E.; Araujo, A.A.M.; Guyot, J.L. Water level dynamics of Amazon wetlands at the watershed scale by satellite altimetry. Int. J. Remote Sens. 2012, 33, 3323-3353. [CrossRef]

193. Schneider, R.; Godiksen, P.N.; Villadsen, H.; Madsen, H.; Bauer-Gottwein, P. Application of CryoSat-2 altimetry data for river analysis and modelling. Hydrol. Earth Syst. Sci. 2017, 21, 651-664. [CrossRef]

194. Huang, Q.; Long, D.; Du, M.D.; Zeng, C.; Li, X.D.; Hou, A.Z.; Hong, Y. An improved approach to monitoring Brahmaputra River water levels using retracked altimetry data. Remote Sens. Environ. 2018, 211, 112-128. [CrossRef]

195. Becker, M.; da Silva, J.S.; Calmant, S.; Robinet, V.; Linguet, L.; Seyler, F. Water Level Fluctuations in the Congo Basin Derived from ENVISAT Satellite Altimetry. Remote Sens. 2014, 6, 9340-9358. [CrossRef]

196. Kim, D.; Lee, H.; Laraque, A.; Tshimanga, R.M.; Yuan, T.; Jung, H.C.; Beighleyg, E.; Chang, C.H. Mapping spatio-temporal water level variations over the central Congo River using PALSAR ScanSAR and Envisat altimetry data. Int. J. Remote Sens. 2017, 38, 7021-7040. [CrossRef]

197. Siddique-E-Akbor, A.H.M.; Hossain, F.; Lee, H.; Shum, C.K. Inter-comparison study of water level estimates derived from hydrodynamic-hydrologic model and satellite altimetry for a complex deltaic environment. Remote Sens. Environ. 2011, 115, 1522-1531. [CrossRef]

198. Pandey, R.K.; Cretaux, J.F.; Berge-Nguyen, M.; Tiwari, V.M.; Drolon, V.; Papa, F.; Calmant, S. Water level estimation by remote sensing for the 2008 flooding of the Kosi River. Int. J. Remote Sens. 2014, 35, 424-440. [CrossRef]

199. Boergens, E.; Dettmering, D.; Schwatke, C.; Seitz, F. Treating the Hooking Effect in Satellite Altimetry Data: A Case Study along the Mekong River and Its Tributaries. Remote Sens. 2016, 8, 91. [CrossRef]

200. Pham, H.T.; Marshall, L.; Johnson, F.; Sharma, A. Deriving daily water levels from satellite altimetry and land surface temperature for sparsely gauged catchments: A case study for the Mekong River. Remote Sens. Environ. 2018, 212, 31-46. [CrossRef]

201. Villadsen, H.; Andersen, O.B.; Stenseng, L.; Nielsen, K.; Knudsen, P. CryoSat-2 altimetry for river level monitoring - Evaluation in the Ganges-Brahmaputra River basin. Remote Sens. Environ. 2015, 168, 80-89. [CrossRef]

202. Boergens, E.; Nielsen, K.; Andersen, O.B.; Dettmering, D.; Seitz, F. River Levels Derived with CryoSat-2 SAR Data ClassificationA Case Study in the Mekong River Basin. Remote Sens. 2017, 9, 1238. [CrossRef] 
203. Liu, K.T.; Tseng, K.H.; Shum, C.K.; Liu, C.Y.; Kuo, C.Y.; Liu, G.M.; Jia, Y.Y.; Shang, K. Assessment of the Impact of Reservoirs in the Upper Mekong River Using Satellite Radar Altimetry and Remote Sensing Imageries. Remote Sens. 2016, 8, 19. [CrossRef]

204. Tarpanelli, A.; Camici, S.; Nielsen, K.; Brocca, L.; Moramarco, T.; Benveniste, J. Potentials and limitations of Sentinel-3 for river discharge assessment. Adv. Sp. Res. 2019. [CrossRef]

205. Paris, A.; de Paiva, R.D.; da Silva, J.S.; Moreira, D.M.; Calmant, S.; Garambois, P.A.; Collischonn, W.; Bonnet, M.P.; Seyler, F. Stage-discharge rating curves based on satellite altimetry and modeled discharge in the Amazon basin. Water Resour. Res. 2016, 52, 3787-3814. [CrossRef]

206. Hou, J.W.; van Dijk, A.; Renzullo, L.J.; Vertessy, R.A. Using modelled discharge to develop satellite-based river gauging: A case study for the Amazon Basin. Hydrol. Earth Syst. Sci. 2018, 22, 6435-6448. [CrossRef]

207. Dubey, A.K.; Gupta, P.; Dutta, S.; Kumar, B. Evaluation of satellite-altimetry-derived river stage variation for the braided Brahmaputra River. Int. J. Remote Sens. 2014, 35, 7815-7827. [CrossRef]

208. Huang, Q.; Long, D.; Du, M.D.; Zeng, C.; Qiao, G.; Li, X.D.; Hou, A.Z.; Hong, Y. Discharge estimation in high-mountain regions with improved methods using multisource remote sensing: A case study of the Upper Brahmaputra River. Remote Sens. Environ. 2018, 219, 115-134. [CrossRef]

209. Kim, D.; Yu, H.W.; Lee, H.; Beighley, E.; Durand, M.; Alsdorf, D.E.; Hwang, E. Ensemble learning regression for estimating river discharges using satellite altimetry data: Central Congo River as a Test-bed. Remote Sens. Environ. 2019, 221, 741-755. [CrossRef]

210. Birkinshaw, S.J.; O’Donnell, G.M.; Moore, P.; Kilsby, C.G.; Fowler, H.J.; Berry, P.A.M. Using satellite altimetry data to augment flow estimation techniques on the Mekong River. Hydrol. Process. 2010, 24, 3811-3825. [CrossRef]

211. Sun, W.C.; Ishidaira, H.; Bastola, S. Towards improving river discharge estimation in ungauged basins: calibration of rainfall-runoff models based on satellite observations of river flow width at basin outlet. Hydrol. Earth Syst. Sci. 2010, 14, 2011-2022. [CrossRef]

212. Sichangi, A.W.; Wang, L.; Hu, Z.D. Estimation of River Discharge Solely from Remote-Sensing Derived Data: An Initial Study Over the Yangtze River. Remote Sens. 2018, 10, 1385. [CrossRef]

213. Ling, F.; Cai, X.B.; Li, W.B.; Xiao, F.; Li, X.D.; Du, Y. Monitoring river discharge with remotely sensed imagery using river island area as an indicator. J. Appl. Remote Sens. 2012, 6, 14. [CrossRef]

214. Bjerklie, D.M.; Birkett, C.M.; Jones, J.W.; Carabajal, C.; Rover, J.A.; Fulton, J.W.; Garambois, P.A. Satellite remote sensing estimation of river discharge: Application to the Yukon River Alaska. J. Hydrol. 2018, 561, 1000-1018. [CrossRef]

215. Kouraev, A.V.; Zakharova, E.A.; Samain, O.; Mognard, N.M.; Cazenave, A. Ob' river discharge from TOPEX/Poseidon satellite altimetry (1992-2002). Remote Sens. Environ. 2004, 93, 238-245. [CrossRef]

216. Chao, N.F.; Wang, Z.T.; Hwang, C.; Jin, T.Y.; Cheng, Y.S. Decline of Geladandong Glacier Elevation in Yangtze River's Source Region: Detection by ICESat and Assessment by Hydroclimatic Data. Remote Sens. 2017, 9, 75. [CrossRef]

217. Wang, R.; Yao, Z.J.; Wu, S.S.; Liu, Z.F. Glacier retreat and its impact on summertime run-off in a high-altitude ungauged catchment. Hydrol. Process. 2017, 31, 3672-3681. [CrossRef]

218. Wang, R.; Yao, Z.J.; Liu, Z.F.; Wu, S.S.; Jiang, L.G.; Wang, L. Snow cover variability and snowmelt in a high-altitude ungauged catchment. Hydrol. Process. 2015, 29, 3665-3676. [CrossRef]

219. Tekeli, A.E.; Akyurek, Z.; Sorman, A.A.; Sensoy, A.; Sorman, A.U. Using MODIS snow cover maps in modeling snowmelt runoff process in the eastern part of Turkey. Remote Sens. Environ. 2005, 97, 216-230. [CrossRef]

220. Akyurek, Z.; Surer, S.; Beser, O. Investigation of the snow-cover dynamics in the Upper Euphrates Basin of Turkey using remotely sensed snow-cover products and hydrometeorological data. Hydrol. Process. 2011, 25, 3637-3648. [CrossRef]

221. Pavelsky, T.M.; Smith, L.C. Spatial and temporal patterns in Arctic river ice breakup observed with MODIS and AVHRR time series. Remote Sens. Environ. 2004, 93, 328-338. [CrossRef]

222. Mermoz, S.; Allain-Bailhache, S.; Bernier, M.; Pottier, E.; Van der Sanden, J.J.; Chokmani, K. Retrieval of River Ice Thickness From C-Band PolSAR Data. IEEE Trans. Geosci. Remote Sens. 2014, 52, 3052-3062. [CrossRef]

223. Sakai, T.; Hatta, S.; Okumura, M.; Hiyama, T.; Yamaguchi, Y.; Inoue, G. Use of Landsat TM/ETM plus to monitor the spatial and temporal extent of spring breakup floods in the Lena River, Siberia. Int. J. Remote Sens. 2015, 36, 719-733. [CrossRef] 
224. Antonova, S.; Duguay, C.R.; Kaab, A.; Heim, B.; Langer, M.; Westermann, S.; Boike, J. Monitoring Bedfast Ice and Ice Phenology in Lakes of the Lena River Delta Using TerraSAR-X Backscatter and Coherence Time Series. Remote Sens. 2016, 8, 903. [CrossRef]

225. Cooley, S.W.; Pavelsky, T.M. Spatial and temporal patterns in Arctic river ice breakup revealed by automated ice detection from MODIS imagery. Remote Sens. Environ. 2016, 175, 310-322. [CrossRef]

226. Antonova, S.; Kaab, A.; Heim, B.; Langer, M.; Boike, J. Spatio-temporal variability of X-band radar backscatter and coherence over the Lena River Delta, Siberia. Remote Sens. Environ. 2016, 182, 169-191. [CrossRef]

227. Stettner, S.; Beamish, A.L.; Bartsch, A.; Heim, B.; Grosse, G.; Roth, A.; Lantuit, H. Monitoring Inter- and Intra-Seasonal Dynamics of Rapidly Degrading Ice-Rich Permafrost Riverbanks in the Lena Delta with TerraSAR-X Time Series. Remote Sens. 2018, 10, 51. [CrossRef]

228. Strozzi, T.; Antonova, S.; Gunther, F.; Matzler, E.; Vieira, G.; Wegmuller, U.; Westermann, S.; Bartsch, A. Sentinel-1 SAR Interferometry for Surface Deformation Monitoring in Low-Land Permafrost Areas. Remote Sens. 2018, 10, 1360. [CrossRef]

229. Whitley, M.A.; Frost, G.V.; Jorgenson, M.T.; Macander, M.J.; Maio, C.V.; Winder, S.G. Assessment of LiDAR and Spectral Techniques for High-Resolution Mapping of Sporadic Permafrost on the Yukon-Kuskokwim Delta, Alaska. Remote Sens. 2018, 10, 258. [CrossRef]

230. Kuenzer, C.; Leinenkugel, P.; Vollmuth, M.; Dech, S. Comparing global land-cover products-Implications for geoscience applications: An investigation for the trans-boundary Mekong Basin. Int. J. Remote Sens. 2014, 35, 2752-2779. [CrossRef]

(C) 2019 by the authors. Licensee MDPI, Basel, Switzerland. This article is an open access article distributed under the terms and conditions of the Creative Commons Attribution (CC BY) license (http:/ / creativecommons.org/licenses/by/4.0/). 